\title{
The Energy Situation in Central Asia: A Comprehensive Energy Review Focusing on Rural Areas
}

\author{
Kedar Mehta ${ }^{1, *}$, Mathias Ehrenwirth ${ }^{1}$, Christoph Trink1 $^{1}$, Wilfried Zörner ${ }^{1}$ and Rick Greenough ${ }^{2}$ \\ 1 Institute of New Energy Systems, Technische Hochschule, 85049 Ingolstadt, Germany; \\ mathias.ehrenwirth@thi.de (M.E.); christoph.trinkl@thi.de (C.T.); wilfried.zoerner@thi.de (W.Z.) \\ 2 Institute of Energy and Sustainable Development, De Montfort University, Leicester LE1 9BH, UK; \\ rgreenough@dmu.ac.uk \\ * Correspondence: kedar.mehta@thi.de; Tel.: +49-841-9348-6681
}

check for updates

Citation: Mehta, K.; Ehrenwirth, M.; Trinkl, C.; Zörner, W.; Greenough, R. The Energy Situation in Central Asia: A Comprehensive Energy Review Focusing on Rural Areas. Energies 2021, 14, 2805. https://doi.org/ $10.3390 /$ en14102805

Academic Editor: Attilio Converti

Received: 8 April 2021

Accepted: 7 May 2021

Published: 13 May 2021

Publisher's Note: MDPI stays neutral with regard to jurisdictional claims in published maps and institutional affiliations.

Copyright: (C) 2021 by the authors. Licensee MDPI, Basel, Switzerland. This article is an open access article distributed under the terms and conditions of the Creative Commons Attribution (CC BY) license (https:// creativecommons.org/licenses/by/ $4.0 /)$.

\begin{abstract}
The northern part of the globe is dominated by industrialisation and is well-developed. For many years, the southern part of the world (South Asia, Africa etc.) has been a target of research concentrating on access to energy (mainly electricity) in rural regions. However, the Central Asian region has not been a focus of energy research compared to South East Asia and Africa. Despite plentiful domestically available energy resources, the energy supply in Central Asia is very unevenly distributed between urban and rural areas. Almost half of the total population of Central Asia lives in rural areas and there is a lack of access to modern energy services to meet primary needs. To analyse the energy situation (i.e., electricity, heating, hot water consumption, cooking, etc.) in rural Central Asia, this paper reviews residential energy consumption trends in rural Central Asian regions as compared to urban areas. Furthermore, the paper illustrates the potential of renewable energies in Central Asia. To perform the study, a qualitative comparative analysis was conducted based on a literature review, data, and statistical information. In summary, the presented article discusses the rural energy situation analytically and provides in-depth insights of Central Asian energy infrastructure.
\end{abstract}

Keywords: Central Asia; energy resources; rural energy supply; energy services; renewable energy

\section{Introduction}

\subsection{Background and Context}

Universal access to affordable and clean energy access by 2030 is one of the goals defined in the United Nations' Sustainable Development Goals (Goal 7). To enable energy access, researchers have proposed several energy-related solutions to meet basic human needs, such as electricity, heating, cooling, clean cooking, etc., and in despite their work, billions of people are still deprived of even primary energy services [1-4]. Hence, universal energy access is considered as one of the most crucial targets among all Sustainable Development Goals.

Carrillo [4] identified that the issue of energy scarcity and energy security are especially critical for rural populations of developing countries. Also, Muhumuza et al. [5] recognised that provision of modern energy services remains a key problem and challenge for rural populations.

Research into energy security in the southern part of the world (especially South East Asia and Africa) has a long tradition, most of which focuses on electricity access in rural regions [6-8]. However, from the energy research point of view, Central Asia has received less attention than other Asian regions. Energy scarcity in Central Asia exists because of multiple dimensions including the geographical context, nature, environmental influence, and international factors [9].

Geographically, Central Asia is facing completely different energy situations as compared to the industrialised countries of the global north as well as the developing global 
south [10]. Central Asia is situated between the Caspian Sea in the west and China in the east and between Afghanistan in the south and Russia in the north. The region consists of the five different former Soviet republics called Kazakhstan, Kyrgyzstan, Tajikistan, Turkmenistan, and Uzbekistan. The basic statistics and demographics of the Central Asian countries are listed in Table 1, which helps to characterise the Central Asian republics from the socio-economic point of view.

Table 1. Key socio-economic indicators of the Central Asian countries in 2018 (data according to [11-15]).

\begin{tabular}{cccccc}
\hline Indicator & Kazakhstan & Turkmenistan & Uzbekistan & Kyrgyzstan & Tajikistan \\
\hline Surface area in $\mathrm{km}^{2}$ & $2,724,902$ & 488,100 & 447,400 & 199,950 & 141,380 \\
\hline Population in million & 18.2 & 5.8 & 32.95 & 6.3 & 9.1 \\
\hline Share of rural population in \% & 43 & 43 & 50 & 64 & USD 8.0 \\
\hline Gross Domestic Product in billion & USD 170 & USD 40.761 & USD 50.49 & USD 7.5 \\
\hline Gross National Income/capita & USD 7970 & USD 6380 & USD 2000 & USD 1130 & USD 990 \\
\hline
\end{tabular}

Several geographical and geopolitical factors are unfavourable for economic development in Central Asia [16,17]. The Central Asian region is geographically distant from the foremost centres of world economic activity. Furthermore, all the Central Asian countries are landlocked with minimal transportation connections inside and outside their borders [18-20]. The limited connectivity between Central Asia and the outside world remains a major hindrance to expanding the trading and commercial sectors [16,21]. Hence, because of the limited economic activity, most of the Central Asian population make their living in the agriculture and forestry sectors $[22,23]$.

Central Asia is a vast region ( $\sim 4$ million $\mathrm{km}^{2}$ and has a total population of $\sim 70$ million), with a diverse range of geographical features and climates [24]. This includes high-altitude regions, a long-range of snowy mountains, sizeable and warm deserts, and plentiful water resources including two inland seas. Deserts mainly occupy the majority of the land area of Kazakhstan, Uzbekistan, and Turkmenistan. The major deserts in Kazakhstan (Kyzyl Kum and Taklamakan) have extreme temperature ranges with seasonal drought. The strong winds are responsible for dust storms in Kazakhstan which result in agricultural land erosion, and the same applies to the deserts in Turkmenistan and Uzbekistan [25-27].

On the other hand, water resources are an essential feature of Kyrgyzstan and Tajikistan. Both countries have extensive mountainous ranges including the Pamir mountain range (Tajikistan) and the Tien Shan mountain range (Kyrgyzstan). These elevated mountainous ranges (up to $7000 \mathrm{~m}$ ) are responsible for the high-altitude characteristic and the cold climatic zone of these countries [28]. The major part of the mountain ranges is permanently covered with snow and glaciers. The glaciers are the origin of natural water resources which flow in different waterways (i.e., rivers, irrigation channels, water streams, etc.) in Kyrgyzstan and Tajikistan [15]. Downstream countries (Uzbekistan and Turkmenistan) are supplied with river water that is used for irrigation of agricultural fields from upstream countries (Tajikistan and Kyrgyzstan) [29,30].

Central Asia's climate is highly variable across the five countries and represents diverse topographical conditions. For instance, Kyrgyzstan has a cold climate and the majority of the land is covered with snow during the wintertime. However, Tajikistan's climate is mainly subtropical and semi-arid, with half of the country's elevations above $3000 \mathrm{~m}$, while $80 \%$ of Turkmenistan area is flat desert [31]. Because of the mountain ranges in the east and southeast, winters are harsh and prolonged with a temperature range of $-25^{\circ} \mathrm{C}$ to $10{ }^{\circ} \mathrm{C}$ with a snow-covered landscape for more than half of the year. The summers across the Central Asian regions are generally warm to hot, with mean temperatures ranging from $10{ }^{\circ} \mathrm{C}$ to $40^{\circ} \mathrm{C}$ [32]. 


\subsection{A Framework of Energy Resources}

Besides its unique geographical and climatic circumstances, Central Asia is endowed with abundant and diverse energy resources, such as natural gas, oil, raw coal, and plentiful untapped renewable energy resources, including hydro, solar, wind, and biomass energy $[9,10]$. Figure 1 indicates the available natural energy resources by country.

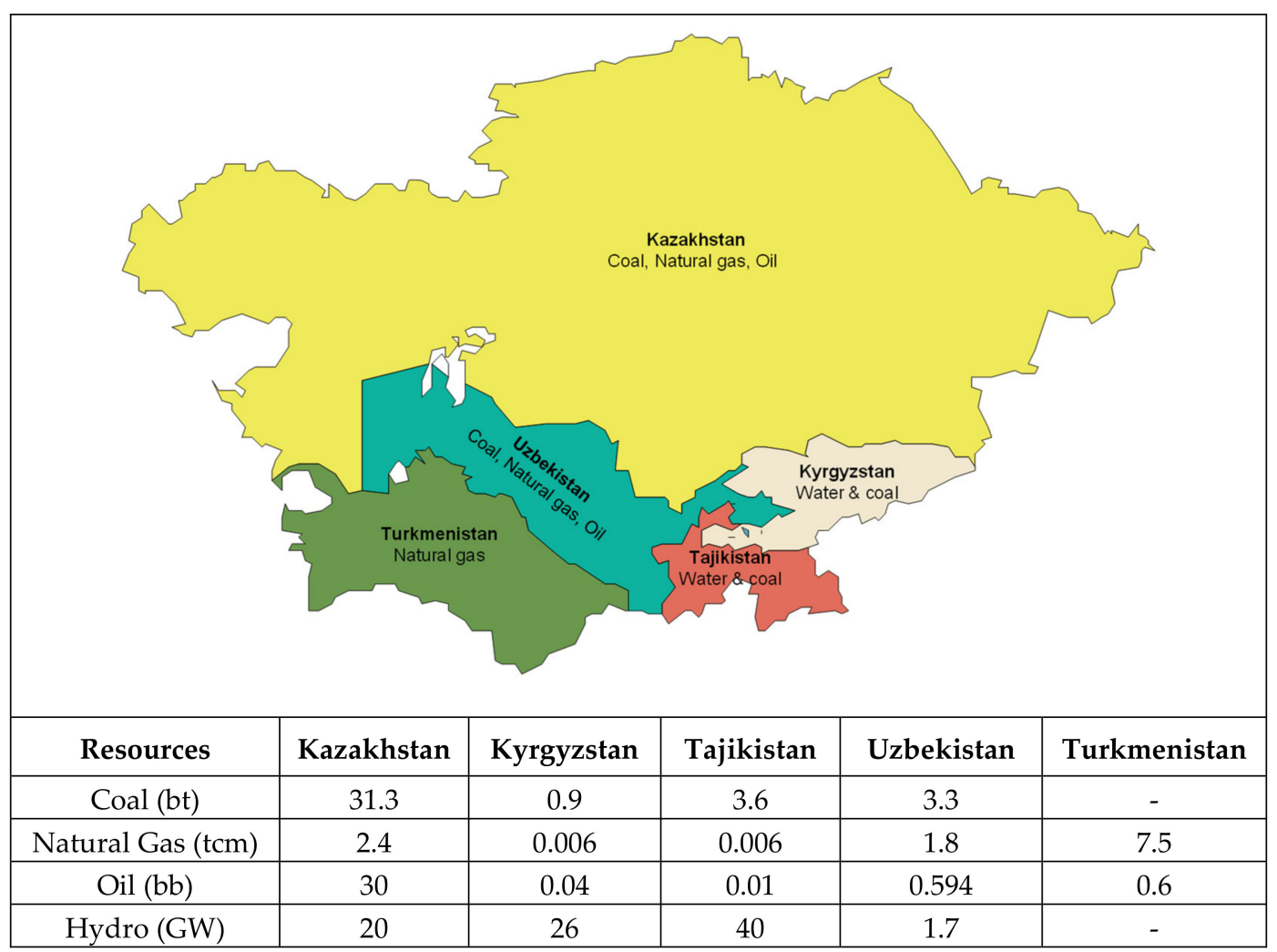

Figure 1. Available energy resources by country $(\mathrm{bt}=$ billion tons, $\mathrm{tcm}=$ trillion cubic meters, $\mathrm{bb}=\mathrm{billion}$ barrels, MW = megawatts) (data according to $[9,10])$.

Kazakhstan is the largest and wealthiest country within the Central Asian region and possesses large oil and coal reserves. Uzbekistan is a significant fossil fuel producer in Central Asia, while Turkmenistan is also a significant energy player in Central Asia, as it has significant natural gas resources and an established thermal power sector [33]. In contrast, Kyrgyzstan and Tajikistan are the smallest and most impoverished countries in the region; however, the very large hydropower resource is concentrated at their disposal. The substantial deposits of fossil fuels are key resources to supply primary energy in Kazakhstan, Turkmenistan, and Uzbekistan. Figure 2 represents the total primary energy supply by various sources in the five countries over the last 25 years [34].

It can be observed from Figure 2 that fossil fuel-based energy supply is a common practice for these countries for the last 25 years. In contrast, Tajikistan and Kyrgyzstan are underprivileged in terms of fossil fuel reservations but fulfil their energy supply mainly from concentrated hydropower. It can be observed from Figure 2 that besides hydropower, other renewable energy (RE) sources are not utilised for energy generation.

Despite its access to diverse energy resources (fossil and non-fossil), Central Asia is facing a complex energy security crisis [10]. The provision of modern, affordable, and reliable energy services remains a challenge, especially in rural Central Asian regions. Rural communities in these regions cannot meet their basic energy needs due to the poor infrastructure of the energy supply systems and geographical isolation from the major energy production centres. 


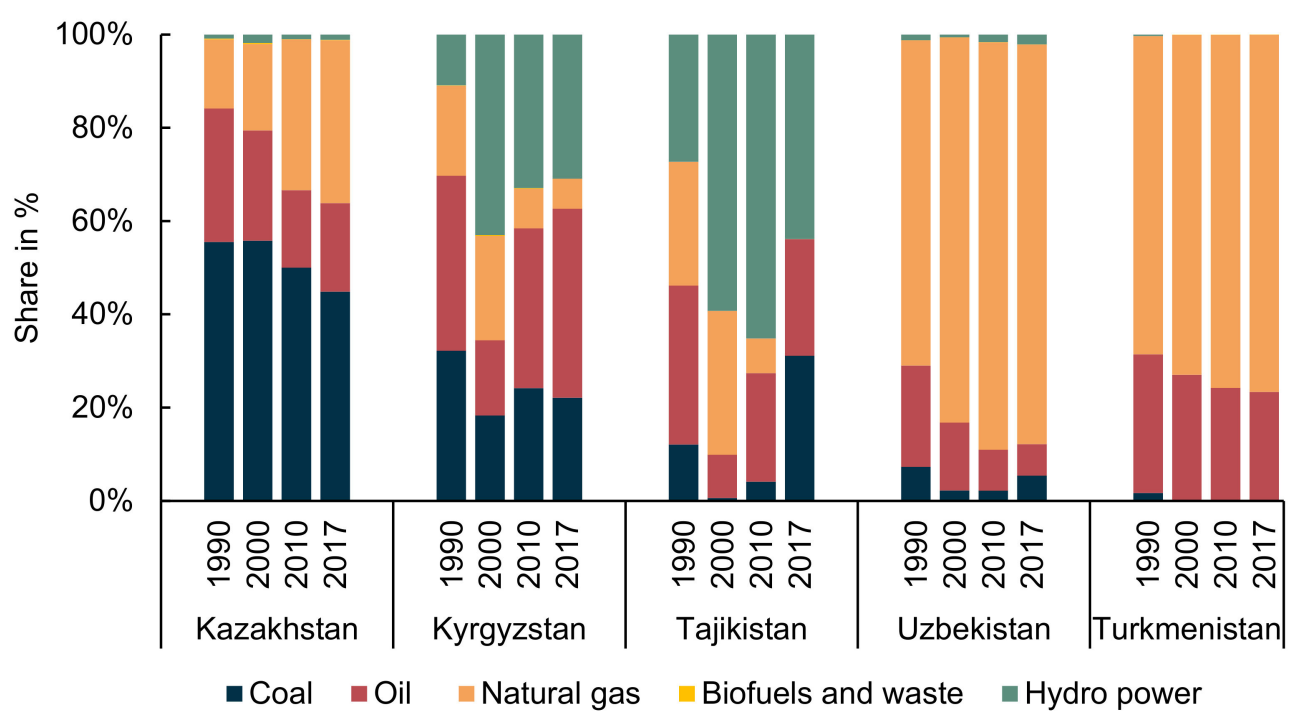

Figure 2. Total Primary Energy Supply in Central Asia by various sources (reproduced from [34], IEA (2019)).

The absence of suitable energy services leads people to use available natural resources to meet their basic energy needs. This heavy reliance on natural resources means considerable exposure to indoor and outdoor air pollution. Mountain societies in Central Asia are highly vulnerable to the impacts of climate change [35-38]. For example, Reyer [39] investigated the ways that Central Asia experiences climate change by presenting various sectors such as energy, water, food, and heat, and suggested that all of these factors will be severely affected by climate change.

\subsection{Objective and Methodology}

After independence in 1991, Turkmenistan and Uzbekistan have been on the track towards a speedy recovery in terms of infrastructural development and access to energy services because of their huge deployment of fossil-fuel resources. The export of the fossil-fuels to neighbouring countries (e.g., exports of natural gas to China and coal to Kyrgyzstan and Tajikistan) yields financial growth and stability to the mentioned Central Asian countries $[16,33,40]$. They then invest these capital inflows in their housing sectors as well as infrastructure development, especially in urban areas. Also, there are very limited information available related to the energy situation in Turkmenistan and Uzbekistan. Hence, this research article focuses on the remaining three countries (Kazakhstan, Kyrgyzstan, and Tajikistan) of Central Asia and investigates their rural energy supplies.

The available scientific information mostly focused on the effects of climate change, the water-energy nexus, and environmental issues in the context of Central Asia [41-45]. However, there is a gap in the literature regarding the distribution of energy services among urban and rural areas in Central Asia. Hence, the research described in this paper aims to perform a comparative analysis and assessment of the current status-quo of energy situation and challenges for selected case study countries of Kazakhstan, Kyrgyzstan, and Tajikistan.

This paper illustrates the current energy supply and consumption trends for various energy sectors of selected countries such as the power sector, heating sector, domestic hot water, and cooking in the rural areas compared to urban areas. Subsequently, the article highlights the potential of renewable energies in Central Asia. In order to perform the study, a qualitative comparative analysis was conducted based on a literature review, followed by the collection of data and statistical information. In summary, the collected information was utilised to display a comprehensive analysis of energy situation in rural Central Asia. Figure 3 displays the methodological approach of the presented article. 


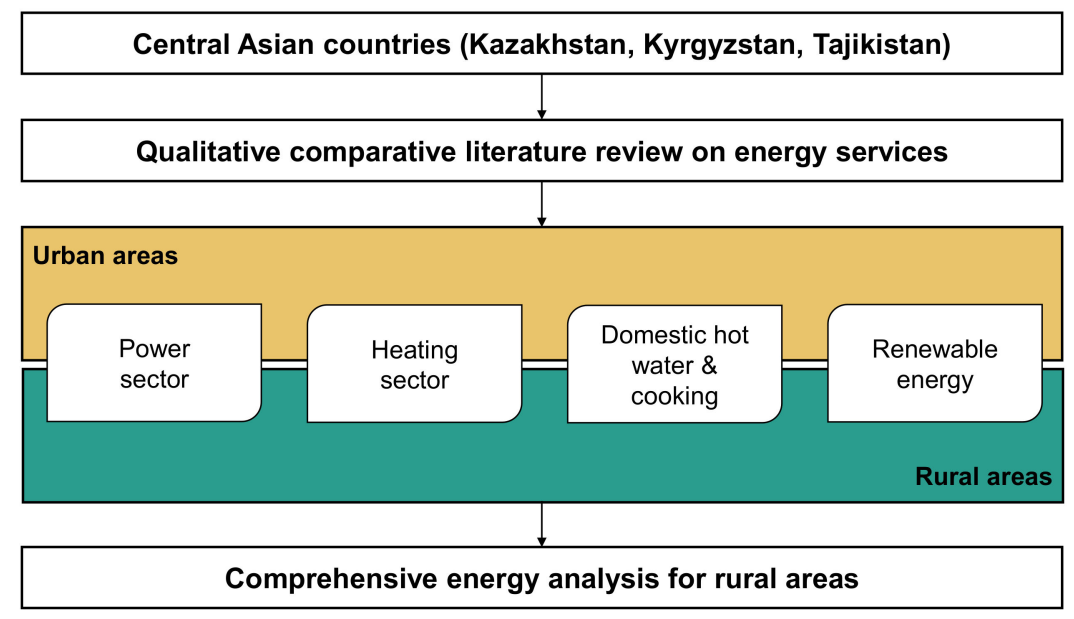

Figure 3. Graphical representation of the concept and structure of the presented review article.

\section{The Central Asian Power Sector}

The availability of plentiful energy resources has resulted in universal electricity access of up to $\sim 100 \%$ in urban and rural areas of Central Asia [46]. The power grid of Central Asia was set up by the Soviets in 1980. However, the infrastructure of the Central Asian power sector is now outdated and is not capable of fulfilling the growing electricity demand of the individual countries [47]. During the 1980s, the power transmission network of the Central Asian countries was interconnected to form the Unified Energy System of Central Asia (UESCA). The UESCA interlinked approximately 83 power plants ( $30 \%$ hydropower plants and $70 \%$ thermal power plants with a total capacity of $25 \mathrm{GW}$ ) located across the Central Asian countries with $220 \mathrm{kV}$ and $500 \mathrm{kV}$ transmission lines. This interconnection allows power to flow across the republics $[48,49]$. However, after independence from the Soviet Union in 1991, the interests of independent Central Asian countries diverged, especially within the energy sector. Turkmenistan and Uzbekistan withdrew themselves from the Unified Energy System in 2003 and 2009, respectively. As a result, Tajikistan was left alone from the unified transmission ring of the Central Asian countries [47,49,50]. Figure 4 represents the integrated Central Asian power network [48].

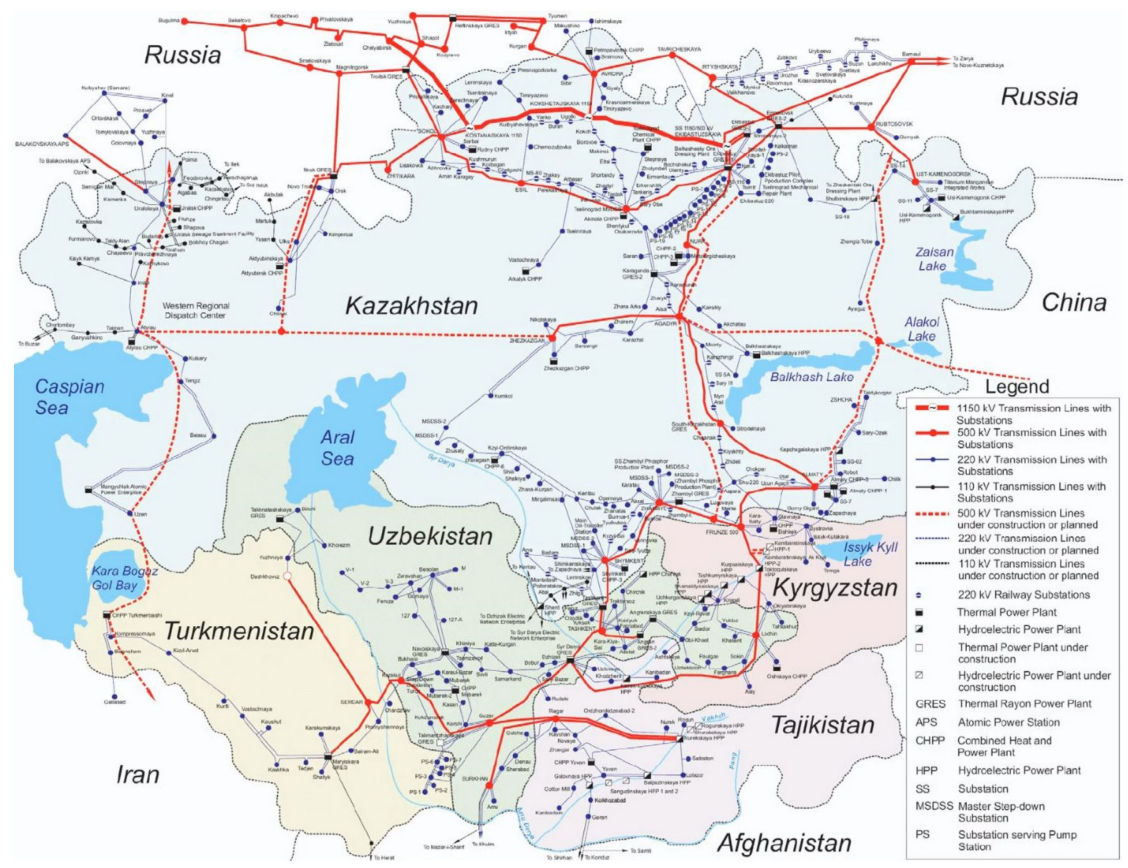

Figure 4. Central Asian power structure [48]. 
Due to the pre-existing electricity distribution system, the regions remain physically interconnected but each country now has its own power generation transmission and distribution strategies. Electricity generation capacity is distributed unevenly in Central Asia. For example, mountainous countries such as Kyrgyzstan and Tajikistan use their water resources to produce hydroelectricity, whereas Kazakhstan produces more than $80 \%$ of its electricity with coal-fired power plants, as the country has large coal resources [51]. Figure 5 represents the distribution of energy resources for electricity generation in Central Asian countries. Despite the widespread access to electricity in the Central Asian regions, the power sectors of individual countries suffer from many problems, the most common of which is the seasonality of supply and demand.

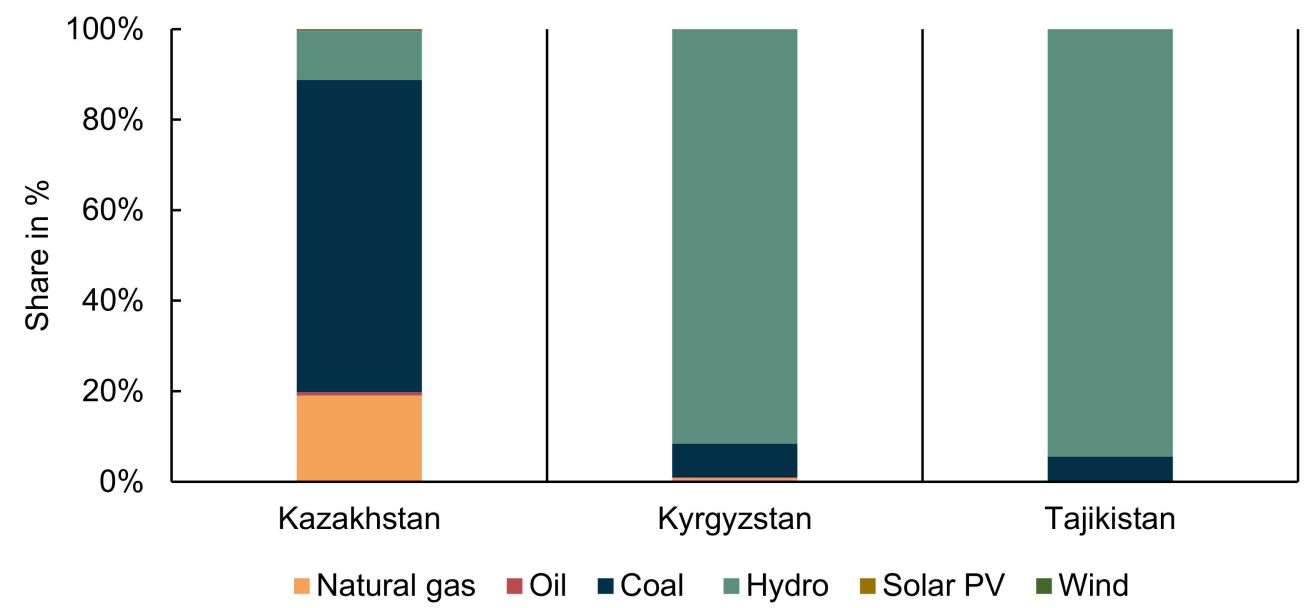

Figure 5. Distribution of energy sources in electricity production (reproduced from [51], IEA (2019)).

The power sectors of Kyrgyzstan and Tajikistan rely mainly on hydro resources, and the power demand of these countries is higher in the winter than in the summer. Due to the cold winters, the river flows decrease, which leads to reduced power production and power shortages. In the summer, the opposite is the case. The regions have therefore established an energy exchange in order to meet seasonal demand. Uzbekistan and Turkmenistan export natural gas to Kazakhstan, Kyrgyzstan, and Tajikistan, while Uzbekistan and Turkmenistan (downstream countries) have minimal water resources and therefore require water to flow from upstream countries (Tajikistan and Kyrgyzstan) for irrigation purposes during the summer and spring.

Kazakhstan, Uzbekistan, and Turkmenistan are directly dependent on their neighbours for water. Because of the winter power shortages, Kyrgyzstan and Tajikistan collect and store water for winter when they experience high power demand. As a consequence, the downstream countries do not receive enough water for agriculture. Because of the unequal and scattered distribution of the energy and water resources in Central Asia, significant tensions can arise between the fossil fuel-rich countries of Kazakhstan, Turkmenistan, and Uzbekistan; and the fossil fuel-poor countries of Tajikistan and Kyrgyzstan [47].

\subsection{Kazakh Power Sector}

Kazakhstan has $4 \%$ of the world's estimated coal reserves ( $\sim 37$ billion tons) and for this reason, more than $80 \%$ of its total electricity is generated in coal operated thermal power plants situated near coal mines [52]. Electricity in Kazakhstan is produced by 128 non-fossil fuels (coal-fired) operated power plants. The total installed capacity of power plants in Kazakhstan is $216.7 \mathrm{GW}$ (some of them are already out of commission) and the available capacity is $187.9 \mathrm{GW}$ [47].

Most of Kazakhstan's power generation facilities are old and obsolete, as they were typically constructed during the past Soviet era and use low-quality fuel $[53,54]$. However, Kazakhstan is considered to be one of the net electricity exporters in the Central Asian 
region and exports mainly to Russia, Uzbekistan, and Kyrgyzstan [54]. On the other hand, the power sector is incapable of maintaining an energy supply and stable frequency during peak loads, so the country needs to import electricity to bridge the gap between demand and supply as well as to regulate frequency [55]. Furthermore, over 40,000 kilometres of the Kazakh transmission and distribution network suffer from high transmission losses. The two main transmission networks are situated in the north (connected to Russia), and the one located in the south is connected to the Unified Energy System of Central Asia [55]. According to the Kazakh Minister of Energy and Natural Resources, "an average of 10\% of its generated electricity is lost before it reaches the consumers due to the widespread deterioration of the power infrastructure" [52]. By comparison, the Kyrgyz and Tajik power sectors, which depend on each country's water resources, resemble each other in terms of energy crises.

\subsection{Kyrgyz Power Sector}

The Tien Shan mountain range covers almost $85 \%$ of Kyrgyz territory, which results in a large number of glaciers and permanent snow. This results in plentiful water resources that have been estimated to add up to $700 \mathrm{~km}^{3}$ [56]. The Naryn river is one of the primary water sources of the country, which originates in the Tian Shan mountains and flows across Kyrgyzstan and Uzbekistan. The enormous hydro resource is responsible for producing around $90 \%$ of total power with different small hydropower plants in Kyrgyzstan [51,57]. Electricity generation in Kyrgyzstan is heavily dominated by hydroelectric power and the rest of the electricity is produced by thermal generators. Most of the hydro powerplants (situated in Naryn cascade) are operated using water released from the Toktogul reservoir, located on the Naryn River in the Jalal-Abad province [58].

The transmission and distribution of electricity in Kyrgyzstan is governed by the National Electric System of Kyrgyzstan (NESK), which is transmitting and distributing control organization for power in Kyrgyzstan [57]. The electrification rate in Kyrgyzstan is around $99.8 \%$, which covers the majority of rural and urban households. Because of the heavy subsidy, the price of grid-supplied electricity in Kyrgyzstan is approximately $0.01 \mathrm{USD} / \mathrm{kWh}$, which is the lowest electricity price in the Central Asian regions [57,58].

In Kyrgyzstan, the energy demand is higher during winter as compared to summer. Hence, there is a significant difference available between interseasonal consumption, which was $2450 \mathrm{GWh}$ in 2012. Furthermore, the winter demand consumption for residential consumers increased by $78 \%$ from 2009 to 2012, mainly because of growing urban areas (migration) and the need for electric-heating in urban areas. To fulfil the energy gap, Kyrgyzstan imports electricity during winter from neighbouring countries (i.e., Tajikistan, Kazakhstan) [58,59]. Figure 6 represents the comparative assessment of residential consumption in winter and summer.

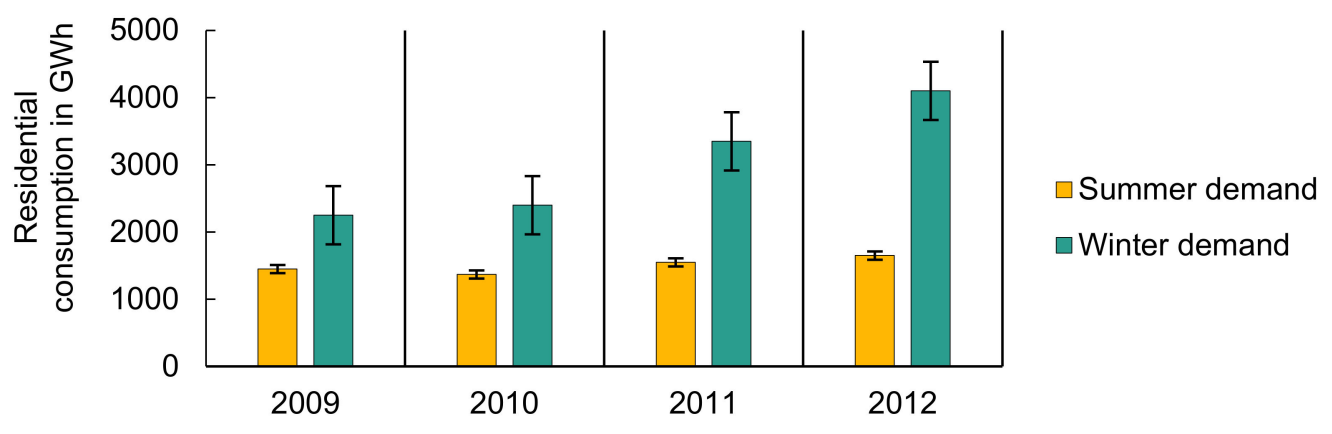

Figure 6. Residential consumption during winter and summertime in Kyrgyzstan (reproduced form [58], Wold Bank (2017)).

The old transmission network results in higher transmission losses (around 30\% of total output annually) [60]. Further to this, the Kyrgyz power sector experiences major concerns involving its supply quality due to its outdated infrastructure. Kyrgyz electricity 
users face an irregular supply of electricity as well as fluctuations in voltage because of reduced power production in the winter season [61,62]. Low-income rural mountainous households apparently experience interruptions in electricity services on a weekly basis [61]. According to the results of a survey of energy delivering services quality in 2015 by the World Bank, around $12 \%$ of Kyrgyz households had uninterrupted power supply, while almost $65 \%$ of households had power cut frequently during the year and $0.5 \%$ had daily power cuts. Additionally, around $50 \%$ of respondents reported problems with voltage (including low voltage and high voltage fluctuations) [61-63]. In summary, only modest improvement was implemented to improve the Kyrgyz power sector's overall performance over the last two and half decades.

\subsection{Tajik Power Sector}

Geographically, Tajikistan is located upstream of the Amu Darya and Syr Darya river basin and therefore is endowed with abundant hydroelectric potential. Therefore, Tajikistan was placed among the list of the world's top 10 countries with the highest hydropower potential. The water resources at the country's disposal are a driving factor and are responsible for more than $90 \%$ of total electricity generation within the power sector framework [64].

Nonetheless, the state of the Tajik power sector is crucial and is facing crises. Nearly all the Tajik houses are connected to the national grid but around $70 \%$ of the population suffers from extensive electricity shortage issues during winter [65]. The freezing winter of Tajikistan is responsible for the reduced natural flow of water, making power production sensitive to available water flow, similar to in Kyrgyzstan. The low production of hydroelectricity and corresponding high electricity demand in winter (for heating) brings disturbances to the demand and supply cycle numerous times during winter. Figure 7 represents electricity consumption by the wealth group and its location. It can be observed that during the heating season, the households in Dushanbe consume electricity significantly (800-900 kWh/month) as compared to low-income rural households (200-300 kWh/month). The urban households frequently use electricity because they can afford it. Meanwhile, because of low-incomes and low power quality, electric heating is less common in rural Tajikistan.

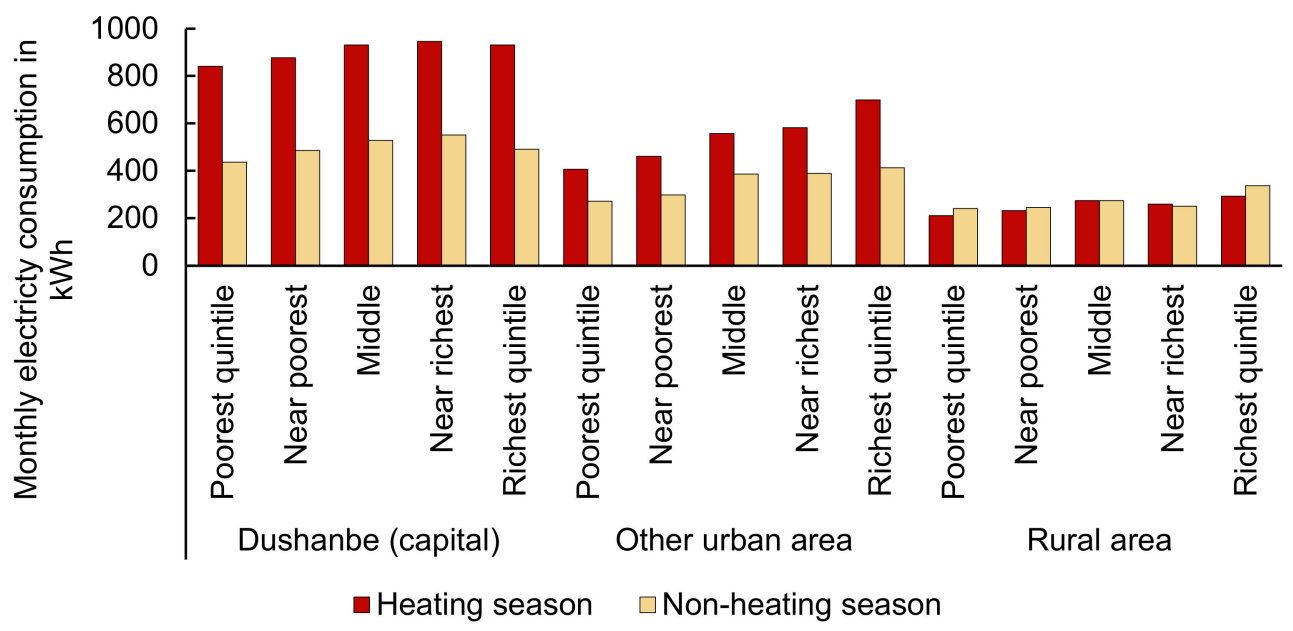

Figure 7. Electricity consumption by wealth group by location and during the heating season and non-heating season (reproduced from [66], World Bank (2014)).

Figure 8 represents the electricity import and export trend as well as electric power transmission and distribution losses of total power output in Kazakhstan, Kyrgyzstan, and Tajikistan over the years. 


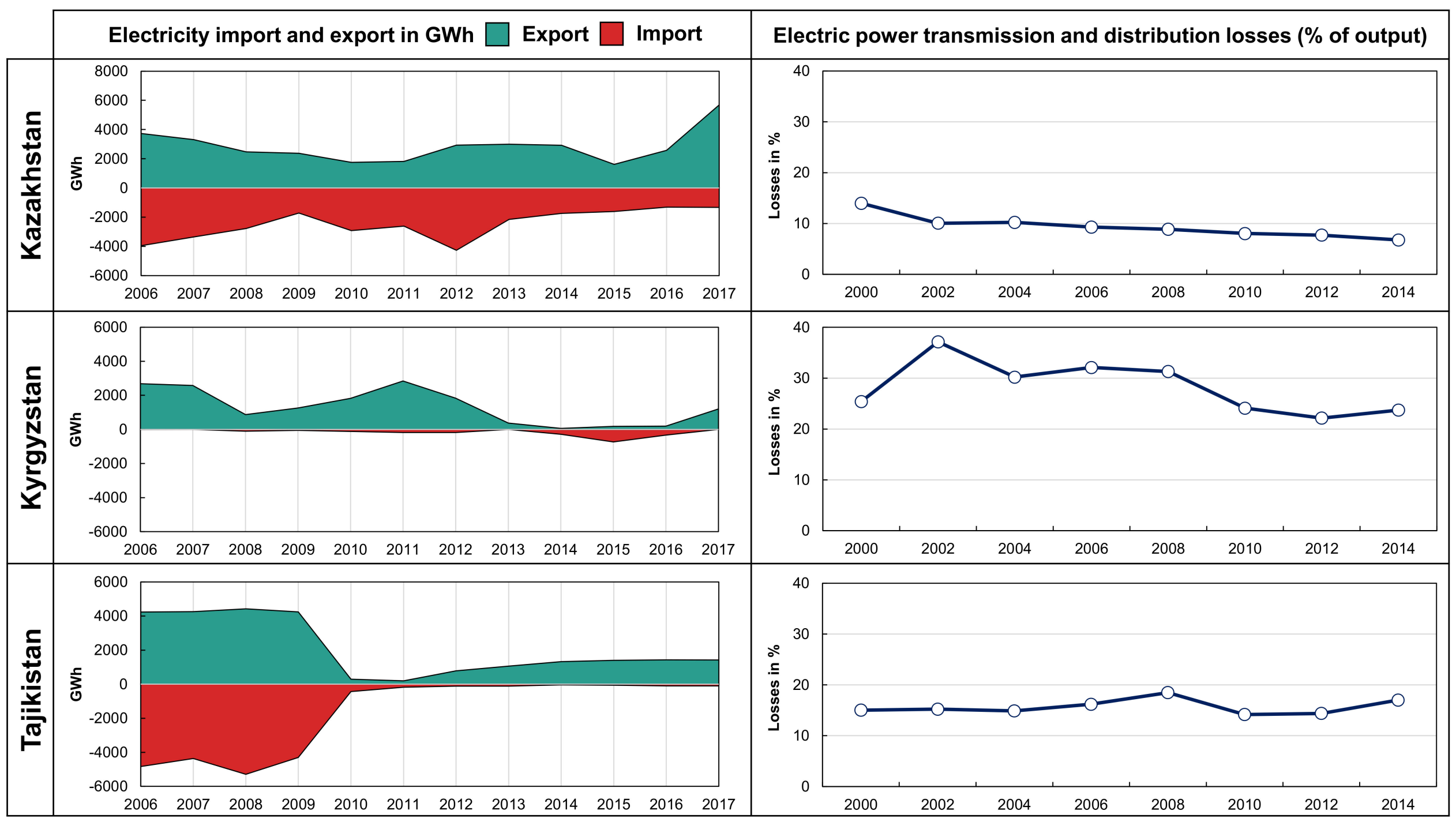

Figure 8. Data on electricity import and export in GWh and electric power transmission and distribution losses in \% of total output [60,67]. 
The high electricity consumption during winter by (urban) Tajik people increases the burden on the power sector. It was estimated that climatic conditions in the winter reduced the generation capacity by around $1250 \mathrm{MW}$ from the various hydropower plants. The reduced generation has resulted in a considerable amount of supply deficit. It has been projected that the winter electricity shortages are at least $2000 \mathrm{GWh}$, nearly $20 \%$ of the total winter electricity demand [68].

The issue of electricity shortage became serious during 2009 when Tajikistan was left separated from the Unified Energy System of Central Asia, and therefore, the inter-border energy trade stopped (c. f. Figure 8). Moreover, the age of the power transmission network aggravates a significant amount of losses ( 30\%; c.f. Figure 8$)$ and contributes to making the winter energy crises more critical $[65,66]$.

An interrupted and unreliable electricity supply has a significant negative influence on business development in Tajikistan. According to the World Bank survey on Business Economic Environment in 2008, 80\% of firms reported that power supply reliability is a key barrier for doing business in Tajikistan [69]. However, the Tajik government has identified the importance of energy security and the impact of energy security on its development. Hence, several measures were introduced which can help to fill the gap of the demand such as energy loss reduction, energy efficiency buildings, and large hydropower plants to generate more electricity [69].

\section{The Central Asian Heating Sector}

Especially in the high-altitude and cold mountain Central Asian regions, more than half of the annual precipitation falls as snow during the winter (generally from November to March) [70]. The heating period is semi-annual in most of the Northern and Central Asian regions, resulting in around 6000 heating degree days [71]. Figure 9 represents the monthly air temperature of selected cities of the case study countries.

\begin{tabular}{|c|c|c|c|c|c|c|c|c|c|c|c|c|c|}
\hline & City & Jan & Feb & Mar & Apr & May & Jun & Jul & Aug & Sep & Oct & Nov & Dec \\
\hline \multirow{3}{*}{ 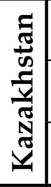 } & Astana & -15.5 & -14.2 & -5.3 & 5.7 & 14.3 & 18.8 & 19.8 & 18.3 & 12.0 & 3.9 & -4.6 & -13.0 \\
\hline & Atyrau & -6.3 & -4.2 & 3.2 & 11.3 & 18.4 & 24.1 & 26.9 & 25.7 & 18.8 & 10.3 & 2.1 & -4.3 \\
\hline & Rudni & -14.0 & -13.2 & -4.7 & 5.2 & 14.3 & 19.0 & 20.4 & 18.8 & 12.9 & 4.7 & -4.0 & -12.3 \\
\hline \multirow{3}{*}{ 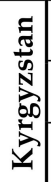 } & Bishkek & -2.7 & 0.4 & 7.8 & 13.0 & 18.6 & 23.7 & 25.4 & 24.3 & 19.0 & 11.6 & 5.4 & -1.5 \\
\hline & Naryn & -14.5 & -10.3 & 0.1 & 8.2 & 12.7 & 15.8 & 17.5 & 17.8 & 13.5 & 6.4 & -0.9 & -11.0 \\
\hline & Talas & -4.2 & -1.6 & 5.2 & 10.3 & 15.6 & 20.0 & 21.0 & 19.9 & 15.1 & 9.0 & 3.3 & -2.7 \\
\hline \multirow{3}{*}{ 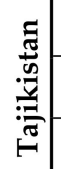 } & Dushanbe & 2.8 & 5.8 & 11.8 & 16.3 & 20.9 & 26.0 & 28.0 & 26.7 & 22.0 & 15.6 & 10.1 & 4.4 \\
\hline & Murghab & -19.0 & -16.5 & -9.5 & -3.0 & 0.5 & 5.0 & 8.5 & 8.5 & 4.0 & -2.0 & -9.0 & -14.5 \\
\hline & Khorog & -6.1 & -4.2 & 2.6 & 10.5 & 15.0 & 19.4 & 22.7 & 22.8 & 13.0 & 11.2 & 4.2 & -2.1 \\
\hline
\end{tabular}

Figure 9. Monthly air temperature heat map of various cities (reproduced from [72], Meteonorm (2018)).

Snow precipitation during winter as well as the cold climatic characteristics of Central Asia with long winters define heating as the primary need of the local people. Therefore, residential energy has a sizable portion in the overall energy consumption framework in Central Asia. It can be observed from Figure 10 that in Kyrgyzstan, residential buildings have the highest share of energy consumption and for Tajikistan and Kazakhstan, residential buildings are the largest energy consumers, followed by the industry sector [73].

It is estimated that almost $60 \%$ to $80 \%$ of buildings in Central Asia are earthen buildings built mainly from soil, clay, and adobe without proper building codes [74]. The age of dwellings in combination with vernacular architecture is a key reason for the high energy utilisation in the residential sector for heating in Central Asia. The absence of modern heat 
energy supply services, low-income, and high heat demand of low energy-efficient building stocks in rural localities promote solid fuel consumption for house heating [71,75]. House heating with solid fuels is common practice in rural Central Asian regions. Generally, rural households used to fuel coal, wood, wood branches, and self-made cow dung in low-efficient traditional heating stoves with a typical thermal efficiency below 40\% [76].

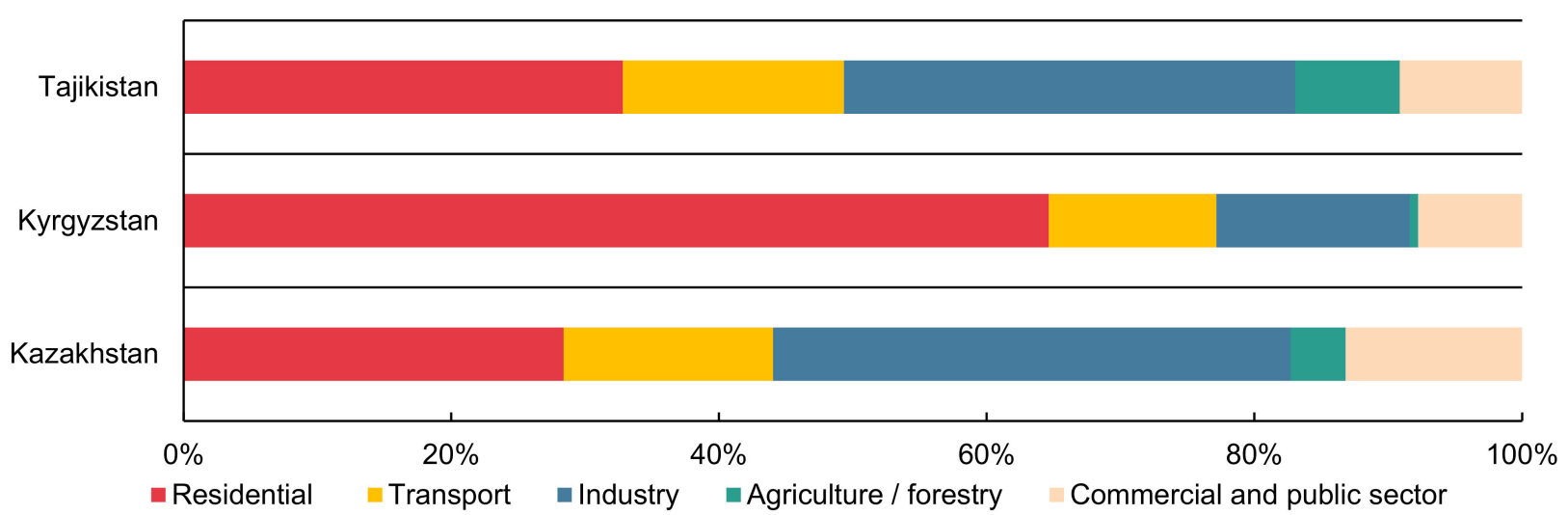

Figure 10. Central Asian total final energy consumption by sectors in 2018 (reproduced from [73], IEA (2020)).

\subsection{Kazakh Heating Sector}

The heating period in Kazakhstan varies from 140 to 230 days (4-8 months) according to the location of the region. The average air temperature in winters ranges from $-16^{\circ} \mathrm{C}$ to $-2{ }^{\circ} \mathrm{C}$ from north to south [77]. The range of sub-zero air temperature underlines that space heating is a basic need for the Kazakh people. The abstracted conventional resources are responsible for the energy-driven economy, and therefore, Kazakhstan is the wealthiest country among the Central Asian regions. Hence, three-fourth of its urban areas have access to the district heating network (DH) (which mostly operates with coal and/or natural gas) and are connected with a natural gas supply. Typically, the households that are not connected to the DH grid (rural homes) rely on coal-based space heating solutions [71,77]. Figure 11 represents the comparison of the heat energy supply distribution of urban and rural areas.

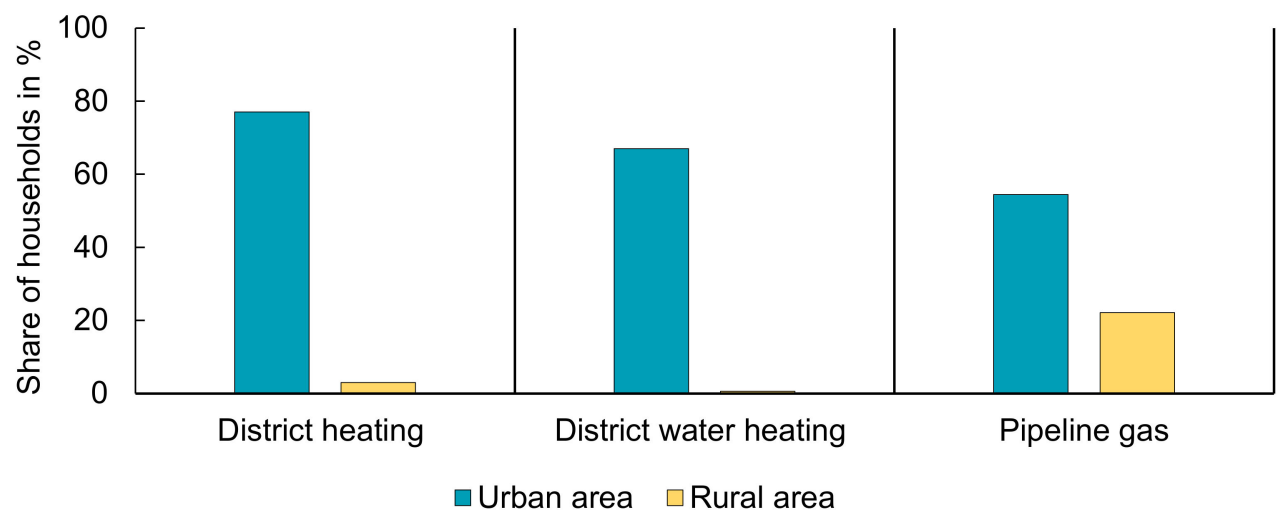

Figure 11. Household access to heat energy services in Kazakhstan during 2014 (reproduced from [71], IAEE (2017)).

Even though with its rich natural energy resources, the semi-urban and rural areas of Kazakhstan are not connected with central heat distribution centres. Therefore, more than $70 \%$ of rural Kazakh dwellings intensively use coal as a primary source for space heating purposes [75]. Howie and Atakhanova [75] estimated that coal consumption for residential heating dramatically increased by almost 45\% between 2002 and 2012. It was observed that consumption increased from 3.9-5.8 tons to 5.6-8.4 tons based on the region because of 
more support towards the coal-based traditional heating approach [75]. It was identified that coal is a key factor that contributes to indoor and outdoor air pollution. This leads to frequent health diseases such as lung cancer, respiratory disorders, and other diseases [78].

\subsection{Kyrgyz Heating Sector}

Kyrgyzstan-one of the low-income countries in Central Asia-has a complex framework for heat energy supply systems, and according to local people, it is not sufficient for heating their homes. Because of limited incomes, accessing energy for primary needs is a costly task for many rural people, especially in mountainous areas [79]. The Kyrgyz weather is characterised and influenced by the mountain ranges covering almost $90 \%$ of the country's territory. The cold climate is responsible for the long heating period of about 6 to 9 months in Kyrgyzstan. To fulfil the domestic space heating requirement, a few houses (17\% of the country's households) mainly in the capital and its nearby areas are connected to the DH network.

The existing DH networks were commissioned around 30 to 50 years ago and hence they run under deteriorating operational conditions, resulting in significant heat losses (around 25-30\%) [63]. As a result, electric radiators are a preferably used by the urban population as a backup heating system. Hence, despite having a DH connection, urban people frequently use an electricity-based domestic heating system during the heating period in Kyrgyzstan. The metropolitan areas that are not connected to the DH network (around 35\% of households) directly depend on electricity for heating. The increased reliance on electricity for heating in urban areas during peak hours results in high residential electricity consumption during winter (c.f. Figure 6) [59,63]. The existing electricity generation capacity directly depends on available water flows, and the distribution network is already strained. The increased reliance on electricity for heating by urban Kyrgyzstan results in recurrent power shortages. Therefore, in a general manner, despite the low electricity tariffs, it is not a reliable option to consider electricity as the primary source of heating in Kyrgyzstan. Further to this, rural settlements/high-altitude rural communities in Kyrgyzstan are typically situated far away from the major energy production centres, and therefore it is not easy to connect remote Kyrgyzstan with the heat energy supply network. Hence, in attempting to meet their space heating needs, rural Kyrgyz people heavily rely on solid fuels operated/fired low-efficient traditional heating stoves or boilers. According to the World Bank, around 73\% of rural homes intensively use non-sustainable biomass / coal to maintain thermal comfort (c.f. Figure 12). Limited income sources and fluctuated electricity service are the prime reasons for rural families to switch to solid fuels to meet their primary needs [63].

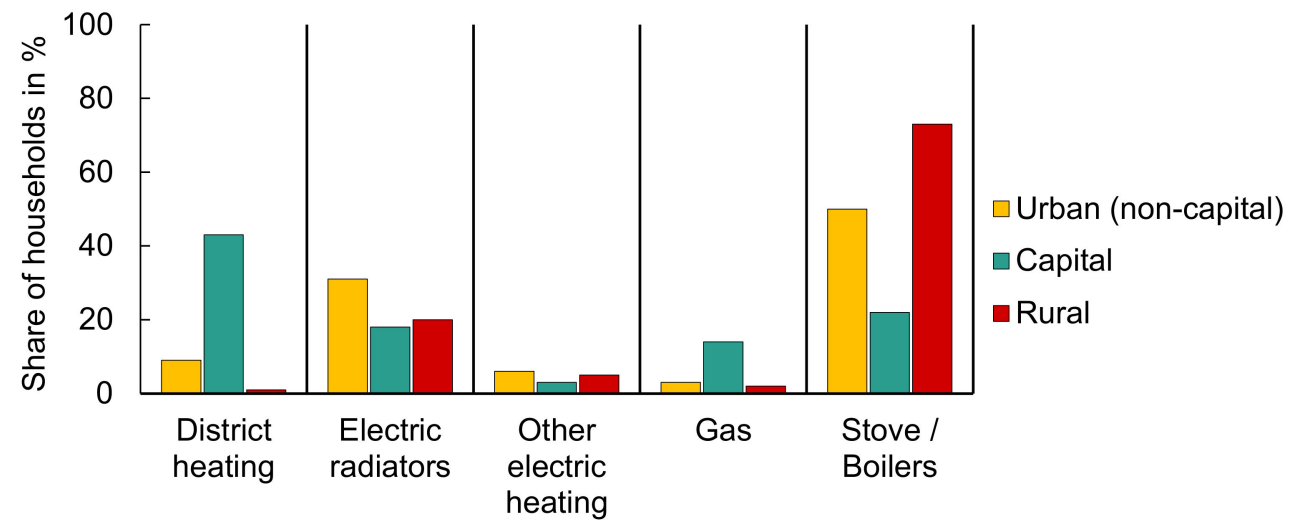

Figure 12. Households' main sources of heating by settlement type (2015) (reproduced from [63], World Bank (2015)).

Rural households in Kyrgyzstan use a variety of solid fuels to meet the residential heat demand. For house heating, most rural families prefer to use coal or wood and, less frequently, animal dung [61]. It is projected that during the heating season, typically, an 
average rural family would need to purchase 2 to 5 tons of coal in combination with 0.5 to 7 cubic meters of firewood and also 5 freight loads of dried cow dung to maintain thermal comfort in the house. Over-usage of non-sustainable firewood is one of the prime reasons for deforestation in Kyrgyzstan [80]. Furthermore, the burning of non-sustainable solid fuels contributes to indoor and outdoor air pollution [81]. In addition, the high reliance on firewood mainly leads to a negative impact on riparian forests of Kyrgyzstan [82]. The typical domestic heating system (traditional heating stove) and solid fuel storage for individual houses are illustrated in Figure 13.

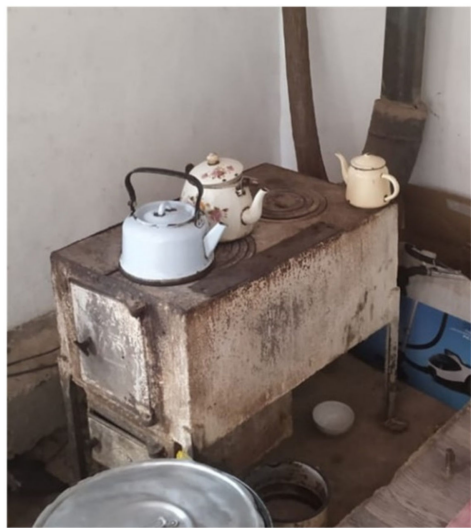

(a)

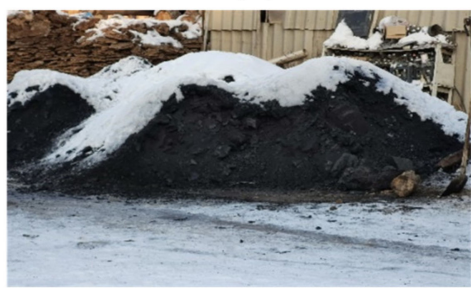

(c)

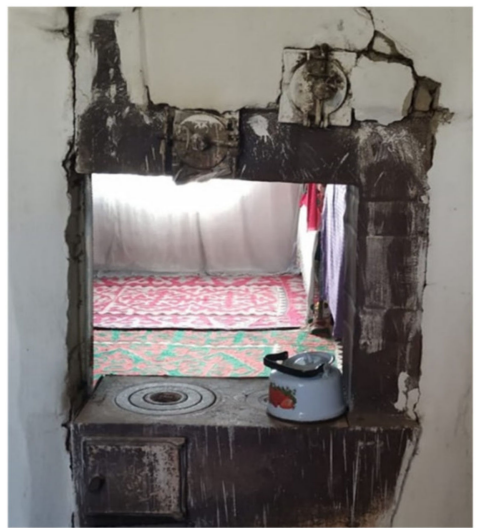

(b)

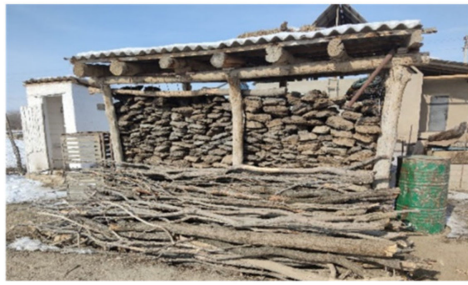

(d)

Figure 13. Traditional heating method in Kyrgyzstan-(a): Traditional heating stove placed at the corner of the room; (b) heating stove that is positioned in the wall between two rooms to heat-up two rooms simultaneously; (c,d) solid fuel storage of an individual household (Source: Authors).

\subsection{Tajik Heating Sector}

Like the Kyrgyz heating sector, the Tajik heating sector faces critical issues with its heat supply. As a result of the outdated DH network as well as the unreliable energy supply, a significant portion of the Tajik population cannot fulfil their residential heat demand. Only $8 \%$ of Tajik houses are connected to the DH network that is characterised by an unreliable service quality. Because of the price increases for natural gas and the inconsistent natural gas supply, most district heating plants in Tajikistan are out of operation. Therefore, like Kyrgyz people, people in urban Tajikistan directly rely on electricity-assisted heating systems. As a consequence, these circumstances aggravate the high electricity demand and increase the burden on transmission networks. This results in extensive shortages of electricity during the winter $[69,83]$.

As a result of substantial unmet energy demand, rural people heavily depend on solid fuels and operate traditional stoves that work inefficiently and are responsible for high ambient air pollution. However, house heating methods differ by energy source, type of dwelling, location, and residents' financial status [66]. Figure 14 categorises primary heating source by building type and location, and it can be observed that around $80 \%$ of multi-apartment buildings in urban areas use electricity as a primary heating source. Generally, high-income families are located in urban areas and, therefore, electric heating is affordable for them. However, middle-income families in urban areas and low-income 
families in rural areas have a high reliance on wood and coal for domestic space heating in Tajikistan [83].

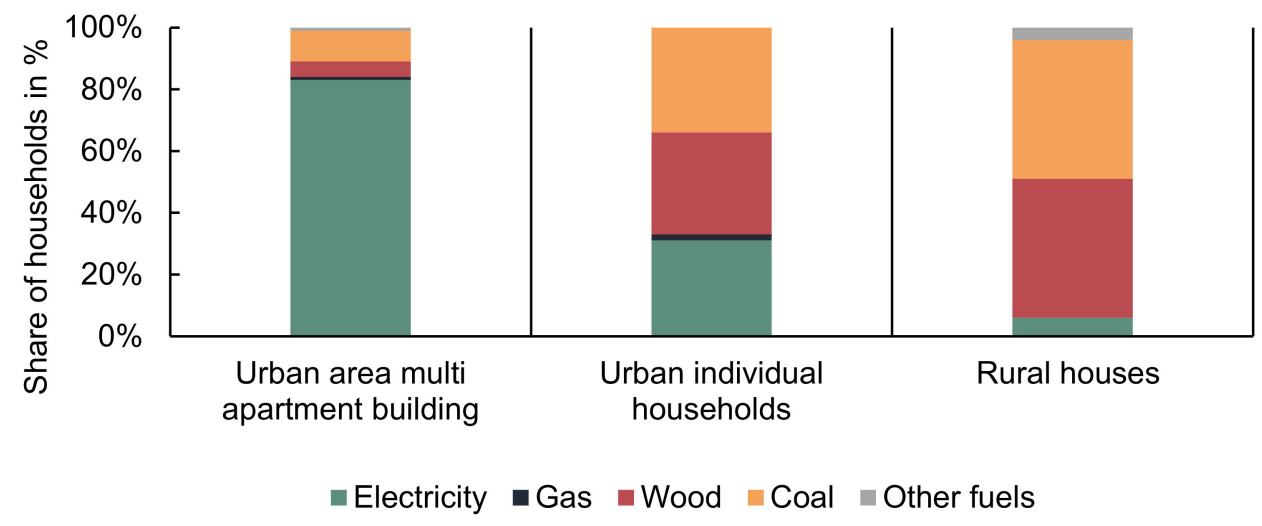

Figure 14. Primary heating source by building type and location in 2015 (reproduced from [66], World Bank (2014)).

The sizeable rural population of Tajikistan would rather not switch to using electricity or any modern heating supply because of the cheap/freely available nature of biomass (i.e., wood and cow-dung); on the contrary, they find electricity is expensive [84]. It can be outlined that the electricity tariff in Tajikistan is 2.32 US cents $/ \mathrm{kWh}$, which is the secondlowest electricity tariff in Central Asia after Kyrgyzstan. The opinions of local people can help to understand the low-income scenarios in rural areas and their support for traditional heating approaches.

Figure 15 characterises a comparative analysis of GDP per capita and death rates from indoor air pollution (the number of deaths per 100,000 individuals). It can be seen that Tajikistan has the highest death rates from indoor air pollution, followed by Kyrgyzstan among the Central Asian regions.

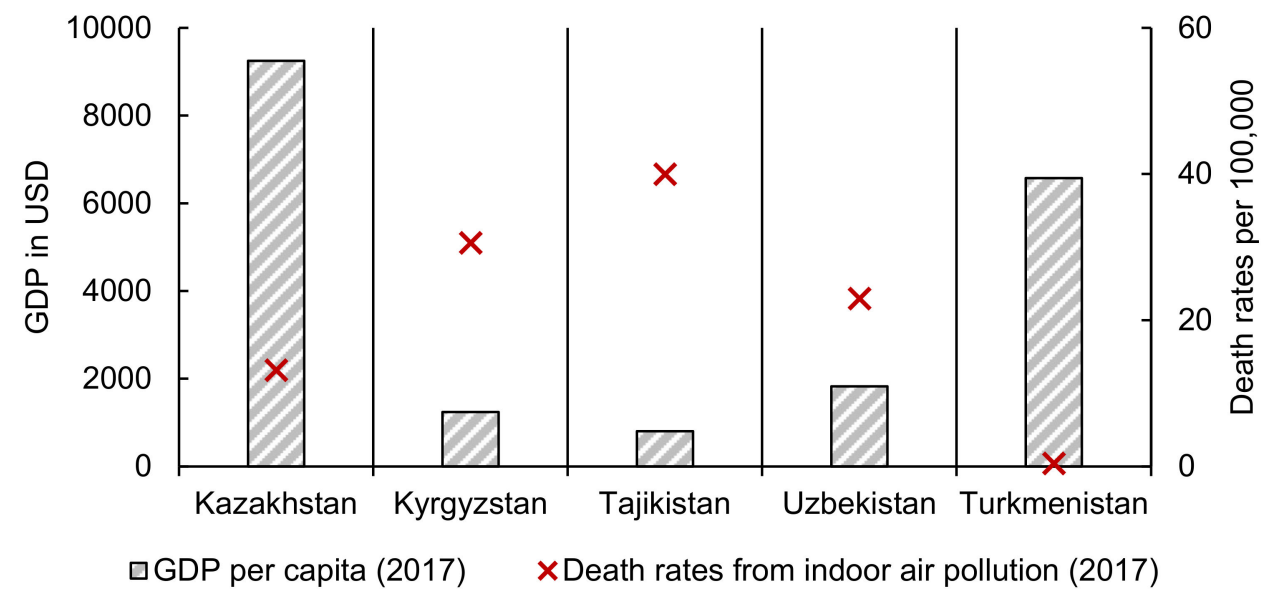

Figure 15. Comparative analysis of GDP per capita (2017) vs. death rates from air pollution (2017) (reproduced from [85,86], World Bank (2017), OWID (2017)).

Table 2 represents the relative description of the energy demand indicator as well as the current energy supply indicator for residential space heating in rural areas of Kazakhstan, Kyrgyzstan, and Tajikistan. 
Table 2. Relative analysis of energy demand and supply indicators for the rural residential space heating sector (data according to $[59,62,63,65,71,83,87,88]$ ).

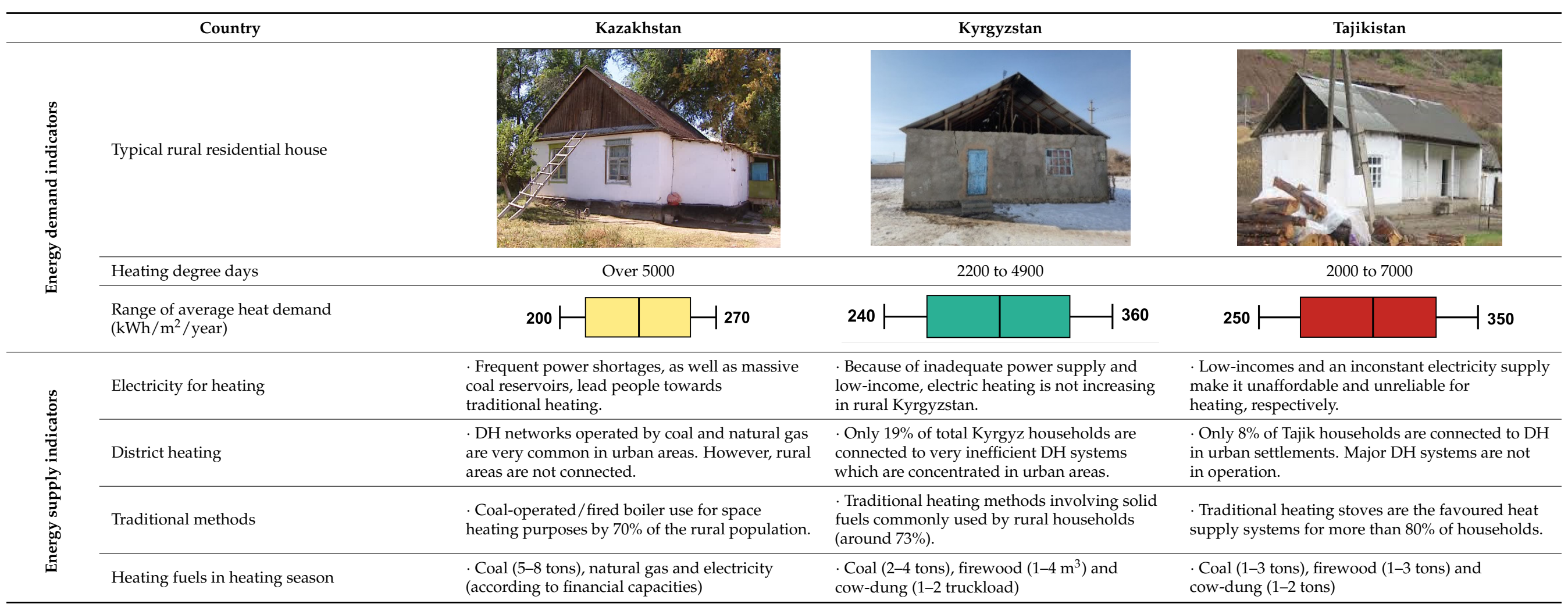




\section{Hot Water Preparation and Cooking in Central Asia}

\subsection{Domestic Hot Water}

Rural areas in Central Asia are less likely to connect with the centralised water supply system and therefore a limited portion of the rural population has access to piped water in the house for drinking water and for other purposes (i.e., domestic hot water preparation, washing, cleaning, etc.). Freshwater resources in Central Asia are mainly classified as surface water bodies and groundwater. The high proportion of usable water comes from high-land rivers (Kyrgyzstan and Tajikistan), which are transboundary rivers [89,90]. Table 3 represents the proportion of population with access to drinking water for the urban and rural population in Kazakhstan, Kyrgyzstan, and Tajikistan.

Table 3. Access to drinking water for population (\%) (reproduced from [89], MDPI (2016)).

\begin{tabular}{cccc}
\hline Area & Kazakhstan & Kyrgyzstan & Tajikistan \\
\hline Urban area & 78 & 85 & 93 \\
\hline Rural area & $>35$ & 58 & 49 \\
\hline
\end{tabular}

It can be concluded from Table 3 that generally, urban areas are supplied with drinking/usable water. In contrast, because of their distant location, rural areas are not strongly connected and have limited access to the central water supplies. Instead, the rural population fetches drinking water from irrigation canals, ditches, and rivers [90]. The low access to the availability of piped water results in limited consumption of hot water. Low-income rural households generally use traditional heating stoves to prepare hot water with a cooking pot (this can be seen in Figure 13) and/or use an electric kettle. Further to this, due to the absence of piped water connections as well as limited income opportunities, typically, rural homes do not have an in-built shower room to take a shower. Rural people use a central/community bathhouse (Banya) to take a shower. Therefore, water consumption in rural areas is limited. The same situation applies with hot water for cooking, washing dishes washing and clothes.

As a result of this very limited hot water use, there is no authentic data source found by the authors which helps to characterise the domestic hot water consumption in urban and rural areas. The households do have precise data on hot water consumption because they fetch the water from outside. Therefore, no water meter is available to measure hot water usage.

\subsection{Cooking Methods and Fuel Sources for Cooking}

The energy sources and access to modern fuels for cooking differ from region to region in Central Asia. In Kazakhstan, because of the widespread availability of Liquified Petroleum Gas (LPG) and electricity, urban populations use them for cooking purpose [91]. However, rural households in Kazakhstan have lower access to gas networks, hence these areas mainly rely on solid fuels (coal and wood) and/or electricity for cooking. Typically, rural people use a combination of fuels for cooking in the same way as for space heating according to their financial capabilities and the season [77].

In Kyrgyzstan, LPG is favourable energy source for cooking in urban areas $(45 \%$ of total households) and electricity for rural areas ( $60 \%$ of total households). However, the sizable population in the rural provinces $(34 \%)$ burns solid fuels for cooking (most commonly wood, followed by cow-dung and agricultural waste) [61].

Due to frequent shortages as well as seasonal interruptions in electricity in Kyrgyzstan and Tajikistan, most rural households prefer to rely on locally available solid fuels. Therefore, according to the availability of electricity, Tajik people prefer electricity for cooking, followed by natural gas ( $42 \%$ and $17 \%$ of rural households, respectively). In addition to this, around 37\% burn solid fuels for cooking in Tajikistan [92]. 


\section{The Potential of Renewable Energy in Central Asia and Current Trend}

Shadrina [93] identified the potential of non-hydropower forms of renewable energy (i.e., solar, wind, biogas etc.) in Central Asia, and revealed that despite their enormous potential, non-hydropower renewable energy is yet to be unleashed. Besides its ample fossil fuel resources, Central Asia has a high potential for RE, which can generate energy sustainably. The abstracted dense river networks in Tajikistan and Kyrgyzstan make them superior for hydro energy [94]. Apart from hydro resources, both countries are blessed with a high potential for solar energy because of their high-altitude characteristics [95]. The potential for solar energy is available in a wide spectrum in Kazakhstan, Uzbekistan, and Turkmenistan as well. Considerable wind energy potential is available in Kazakhstan and Turkmenistan, followed by solar energy [64,96-98].

Kyrgyzstan formulated an energy-related policy in 2008 to accelerate these alternative energy sources. However, there was no remarkable progress achieved to expand the Kyrgyz RE sector. Baybagyshov and Degembaeva [99] mentioned that the low solvency as well as limited incentives from the government for RE technologies are the key reasons for the limited expansion of RE in Kyrgyzstan to date. Similarly, Tajikistan also adopted several program documents to expand the RE sector. However, there are inconsistencies for meeting the target in Tajikistan. To meet their growing demand, Kyrgyzstan and Tajikistan keep increasing the installed capacity of hydropower because of their abundant hydro resources. In contrast, other RE resources are mainly untapped. Uzbekistan also uses very limited hydro resources to produce electricity. In addition, its major solar energy potential is untapped and it has no industrial-scale solar power plants. Also, wind potential has not been studied scientifically and is considered as a gap in local research. To foster RE development, Uzbekistan is taking selective measures to establish proper energy legislation. RE development in Turkmenistan is negligible, as Turkmenistan is heavily reliant on natural gas power generation [100].

Figure 16 portrays the trend of the installed renewable energy capacity in Central Asia over the last 20 years. Because of the insignificant contribution of RE sources, Turkmenistan is excluded from the representation. It can be determined from Figure 16 that apart from hydro energy, the employment of other RE resources is mainly untapped. However, Kazakhstan has noticeable progress in RE development.

On the other hand, a growing body of literature provided evidence that the available RE sources have a phenomenal potential to generate energy to meet unmet demand in Central Asia. Table 4 characterises the literature matrix of selected research articles that focuses on individual countries and their RE potential. It is not practical to present the study of an individual country's RE profile. Therefore, the literature matrix can guide a list of key literature to understand the RE profile of individual republics (Kazakhstan, Kyrgyzstan and Tajikistan) as well as Central Asia as a whole (which covers Uzbekistan as well as Turkmenistan). The detailed investigation in Table 4 identifies that the unique characteristics of the Central Asian region offer a significant potential for renewable energies, which include hydro energy, solar energy, wind energy, biomass energy, and geothermal energy according to the geographical location of the region. However, the available RE sources are usually not exploited in favour of local rural communities. The current energy policies and legislative framework, especially in Kyrgyzstan and Tajikistan, are considered as key barriers to producing electricity with RE sources. The non-cost-effective electricity tariff is significantly below the estimated cost of energy generation from alternative sources. Therefore, investors are not motivated enough to invest in the RE sector. Furthermore, it has been commonly observed in Central Asia that potential investors struggle to obtain loan/finance from regional banks. As a result of this limited financial support, the high capital investment cannot be supported by the investors. Besides investment complexity, special and technical knowledge of RE is either missing or lacking in Central Asia, as there are limited technology providers and knowledge distributors in the local RE sector $[64,96,101]$. 
Table 4. Literature matrix to assess the potential of renewable energy in Central Asia.

\begin{tabular}{|c|c|c|c|c|}
\hline & Author & Research Title & Research Aim & Key Findings \\
\hline \multirow{4}{*}{ 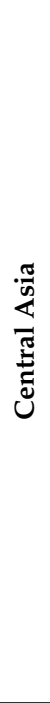 } & Shardina (2020) [93] & $\begin{array}{l}\text { Non-Hydropower Renewable Energy in Central Asia: } \\
\text { Assessment of Deployment Status and Analysis of } \\
\text { Underlying Factors }\end{array}$ & $\begin{array}{l}\text { This paper aimed to assess the reasons behind the } \\
\text { untapped and limited development of RE sectors in } \\
\text { Central Asian countries. }\end{array}$ & $\begin{array}{l}\text { The article summarises that RE sources are } \\
\text { distributed unevenly, and the author also } \\
\text { suggested policy implications to improve the } \\
\text { commitment to RE in Central Asia. }\end{array}$ \\
\hline & Nurdavletova and Akatayeva (2018) [96] & $\begin{array}{l}\text { The renewable energy in the regional development of } \\
\text { Central Asia }\end{array}$ & $\begin{array}{l}\text { The main objective of the article was to investigate } \\
\text { the available alternative sources in Central Asia and } \\
\text { inter-regional complexity. }\end{array}$ & $\begin{array}{l}\text { The article provided a glance at the potential of the } \\
\text { RE sector in individual countries and key hurdles } \\
\text { in detail for the implementation of RE in Central } \\
\text { Asian republics. }\end{array}$ \\
\hline & Gubaidullina et al. (2017) [104] & $\begin{array}{l}\text { Renewable energy and the regional prospect on } \\
\text { sustainable development of Central Asia }\end{array}$ & $\begin{array}{l}\text { The paper aimed to provide useful information on } \\
\text { the issues of renewable energy in Central Asia, as } \\
\text { well as the insight of RE status for } \\
\text { individual countries. }\end{array}$ & $\begin{array}{l}\text { The most rapid development in the field of } \\
\text { renewable energy is noticed in Kazakhstan and the } \\
\text { least developed sphere of RES is in Turkmenistan. }\end{array}$ \\
\hline & Kiseleva et al. (2017) [105] & $\begin{array}{l}\text { Efficiency estimation for the grid-tie photovoltaic } \\
\text { stations construction in some regions of Central Asia } \\
\text { and Transcaucasia }\end{array}$ & $\begin{array}{l}\text { This techno-economic assessment evaluated the } \\
\text { construction of network PV farm ( } 5 \mathrm{MW}) \text { in selected } \\
\text { regions of Central Asian countries. }\end{array}$ & $\begin{array}{l}\text { By consideration of local feed-in tariffs, the simple } \\
\text { payback period was determined to last } 4-6 \text { years in } \\
\text { different regions of Central Asia for small scale PV } \\
\text { farms }(5 \mathrm{MW}) \text {. }\end{array}$ \\
\hline \multirow[t]{2}{*}{ 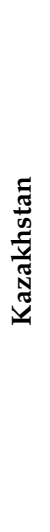 } & Vakhguelt (2017) [107] & Renewable Energy Potential of Kazakhstan & $\begin{array}{l}\text { The article presents the recent status quo of available } \\
\text { potential of hydropower, wind power, solar power, } \\
\text { geothermal energy, and bioenergy and their available } \\
\text { operations in Kazakhstan. }\end{array}$ & $\begin{array}{l}\text { Kazakhstan has a great potential for renewable } \\
\text { energy production. Most of the Kazakh territory } \\
\text { has great solar potential as well as considerable } \\
\text { wind energy. }\end{array}$ \\
\hline & Karatayev et al. (2016) [108] & $\begin{array}{l}\text { Renewable energy technology uptake in Kazakhstan: } \\
\text { Policy drivers and barriers in a transitional economy }\end{array}$ & $\begin{array}{l}\text { With the help of the analytical hierarchy process, this } \\
\text { paper investigates and ranks the different barriers } \\
\text { towards the adoption of renewable energy in } \\
\text { Kazakhstan. Also, it provides interesting insights } \\
\text { into the country's legal framework. }\end{array}$ & $\begin{array}{l}\text { It was identified that sustainable and affordable RE } \\
\text { systems toned to be introduced in Kazakhstan for } \\
\text { low carbon energy generation. Despite abundant } \\
\text { available RE resources renewable energy currently } \\
\text { contributes to less than } 1 \% \text { of the country's } \\
\text { power generation. }\end{array}$ \\
\hline
\end{tabular}


Table 4. Cont.

Author

Research Title

Comparative Analysis of Some Types of Renewable Energy Sources

\section{空}

Abidov et al. (2020) [109]

Baybagyshov and Degembaeva (2019) [99] Analysis of the usage of renewable energy

Baybagyshov and Degembaeva (2019) [99] $\begin{aligned} & \text { Analysis of the usage of renewable energy } \\ & \text { in Kyrgyzstan }\end{aligned}$

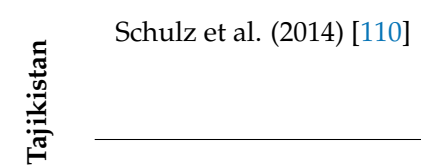

The energy supply for mountain settlements in Tajikistan based on renewable energy sources

Doukas et al. (2012) [111]
Promoting renewables in the energy sector of Tajikistan

\section{Research Aim}

Key Findings

The article discussed the current state and possibilities of using alternative energy in Kyrgyzstan. It also assessed non-traditional renewable energy sources as well as the economic efficiency and its payback period.

The manuscript defined the analysis results of the opportunity of using renewable energies (Solar, wind, hydro, biomass, and geothermal) in Kyrgyzstan.

This article investigated the electrification of mountain settlements/communities of Tajikistan by means of combined forms of renewable energy sources (i.e., a small hybrid hydropower station, small PV station).

The document presented multi-dimensional approach to identify the suitability of decentralise heat production in Tajikistan.
The article identified that each type of RE source has its positive benefits in various regions of Kyrgyzstan. It also explained the reasons behind the insufficient use of RE in Kyrgyzstan.

The analysis showed that the country has a great potential for renewable energy, which is

unexploited. The use of renewable energy for Kyrgyzstan should be considered as a solution to population's socio-economic problems in the decentralised high-altitude regions region.

The article claimed that there is an immediate need to solve the seasonal deficiency of the Tajik power sector. It suggests that a small-scale hybrid power station operated by combined RE sources will be suitable for sustainable electricity supply for remote settlements in Tajikistan.

Technically, a low-pressure solar water heater is a more suitable design for Tajikistan. Also, the pape identified the hurdles for further development of decentralised heat production. 


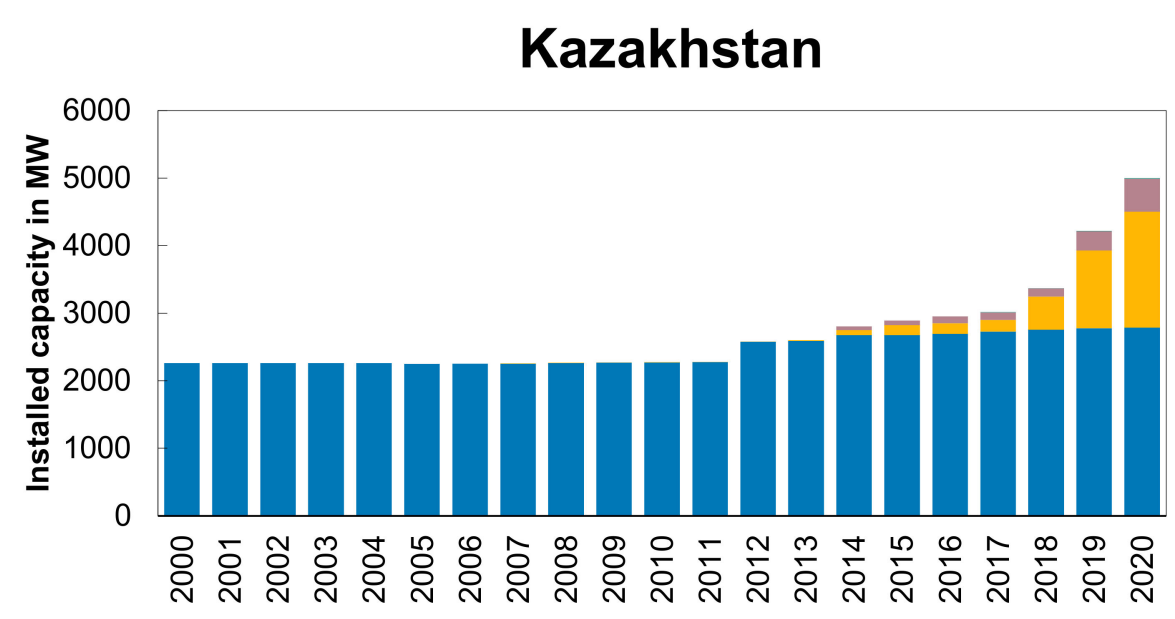

Tajikistan

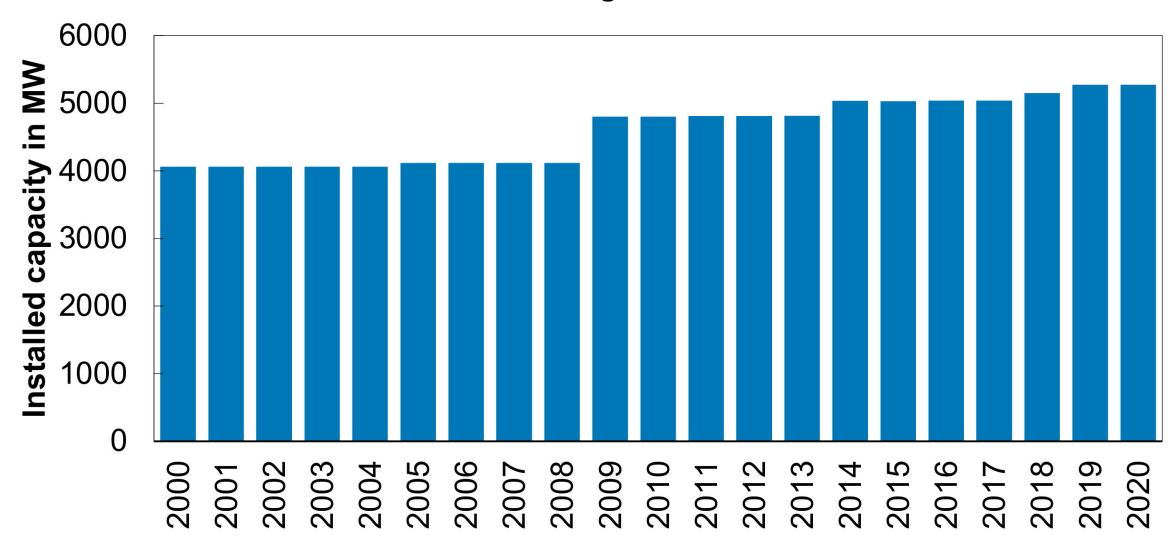

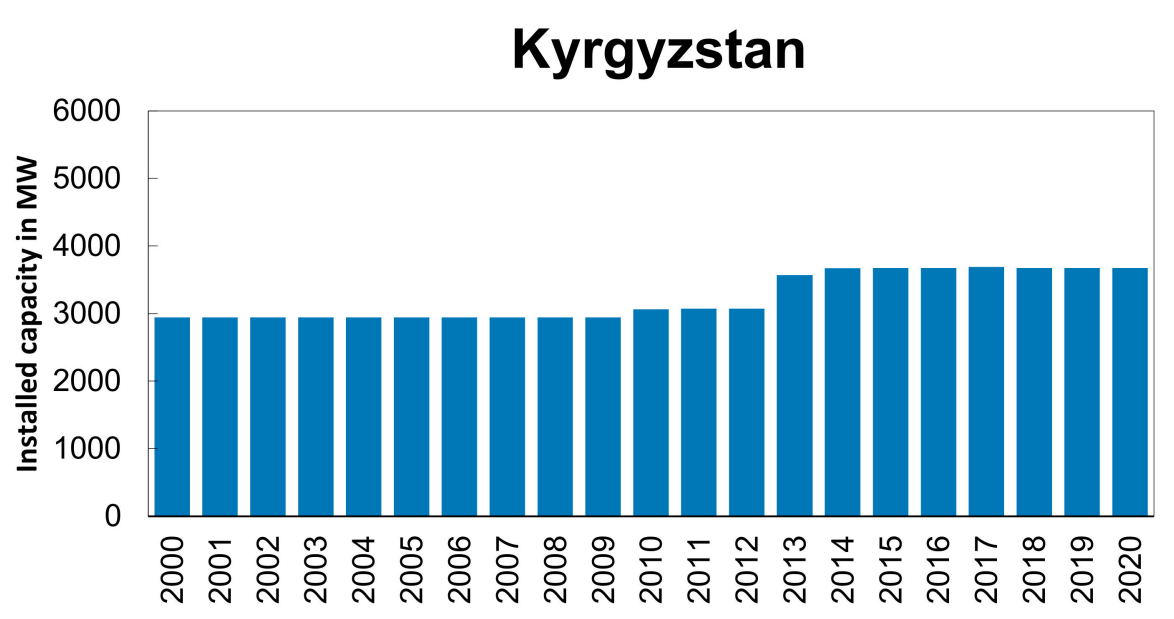

Uzbekistan

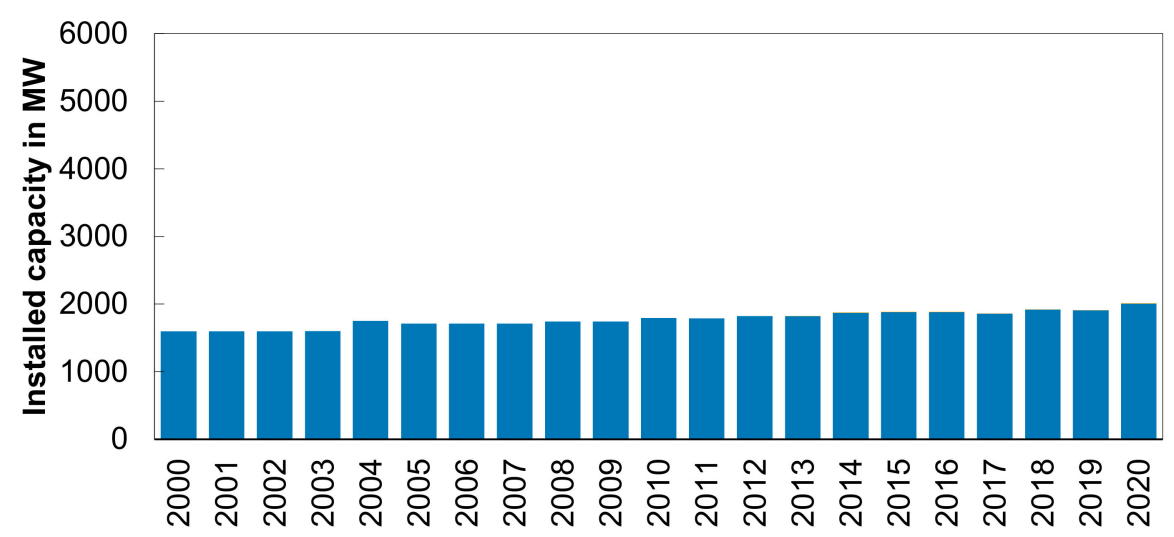

Renewable hydro

Solar PV

Onshore wind

Biogas

Figure 16. The trend of installed renewable energy capacity in Central Asian countries (reproduced from [102], IRENA (2020)) 


\section{Analytical Discussion and Future Perspectives}

The previous sections of the article provided the background and detailed information required to realise the complexity associated with the energy supply in rural Central Asia. The key idea of the presented article was to review and display the comprehensive energy situation of rural Central Asia. The key findings from the review article are listed below:

- According to the climatic situation of Central Asia, space heating is a necessary energy need for local people. Therefore, most of the energy is consumed for domestic heating as compared to cooking and lighting.

- Because of the Soviet Union's development in the late 1990s, all Central Asian countries are nearly electrified. However, the transmission lines and the power sector of Kazakhstan, Kyrgyzstan, and Tajikistan are obsolete and facing a similar issue of interseasonal demand. This can be immediately linked with the heating sectors of these countries. The provision of the DH network is mainly concentrated in the urban areas, and therefore, the urban households more often use electric heating systems. This increases the burden on the power sector and causes persistent shortages/outages. The low-population remote settlements lose power supply first. Hence, the actual electricity access is neither reliable nor affordable, especially for rural people. Hence, to meet primary energy needs, the rural population intensively use solid fuels.

- Rural settlements in Central Asia experience a high degree of energy scarcity and vulnerability. The majority of the rural population directly depends on the environment and fulfil their basic energy needs with the traditional approach/non-sustainable solid fuels.

- It can be identified from the presented review article that the energy infrastructure of Central Asia plays a critical role in terms of energy access.

- Central Asia is endowed with a great amount of RE resources. However, the renewable sector is not yet exploited because of the limited infrastructure, current energy policies, and a lack of scientific knowledge.

- To enhance the energy supply and services, the untapped RE resources in Central Asia are the most suitable resources for establishing sustainability in rural Central Asia.

Figure 17 provides a conceptual representation of a typical thematic solution which can be considered as future perspective. Also, it listed the key drivers (local boundary conditions) which influence the provision of energy services in rural Central Asia.

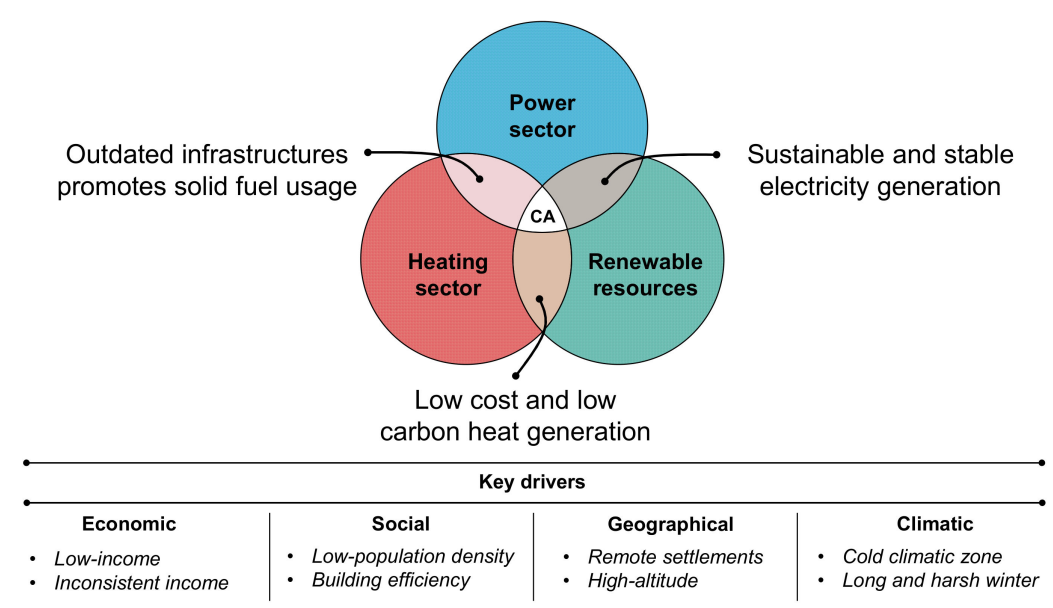

Figure 17. Thematic solution and key drivers which influence the provision of energy services in rural Central Asia (CA).

To reduce energy insecurity in rural areas, RE sources can be utilised to provide sustainable and stable electricity (i.e., solar photovoltaic farms). This solution can reduce the burden on the national grid, as additional stable power generation can be achieved with one of the RE sources. Similarly, RE sources can be potentially utilised to provide 
low cost and low-carbon domestic heating solutions (i.e., solar thermal collectors, solar air heaters, etc.). For example, Mehta et al. [112] identified that a solar-thermal heating system has a high potential for sustainable heat supply on the residential level, while the integration of solar-thermal operated system contributes to reducing the considerable amount of non-sustainable solid fuels of high-altitude rural Central Asian (Kyrgyz) houses.

However, to increase the viability of the proposed thematic solution, one needs to address the key drivers (local boundary conditions) mentioned in Figure 16, such as social, geographical, climatic, and economic dimensions while designing energy supply solutions. Future studies could examine a detailed assessment of energy supply systems based on RE to investigate the viability and impact of RE on the provision of energy services in rural Central Asia from a techno-economic point of view.

\section{Conclusions}

Central Asian countries face energy crises, especially for energy security and energy services provision to the rural citizen. Like other developing countries, Central Asia's urban regions are developed and have access to modern energy services to fulfil primary energy needs. Arguably, Central Asia's rural settlements are more critical in terms of the provision of energy services to meet basic energy needs.

The rural regions in Central Asia are mainly marginalised and geographically isolated from the main economic and central energy production centres. Because of the limited communication in the context of modern energy supply, rural people excessively depend on natural resources such as solid fuels, agricultural waste, and charcoal for their daily energy needs. Hence, the provision of energy services has a high degree of deviation between urban Central Asia and rural Central Asia. The very limited availability of energy information for Turkmenistan and Uzbekistan makes them challenging to examine and compare in the presented study. Hence, the comprehensive analysis was performed for the remaining Central Asian countries: Kazakhstan, Kyrgyzstan, and Tajikistan.

It can be determined from the presented review that there is a strong link between household income level and energy behaviour. Moreover, despite the enormous renewable energy resources, the transition in the renewable energy sector is not considerable, and all the renewable energy sources are mainly untapped. The analytical discussion identified that the utilisation of renewable energy can be a suitable solution to improve energy services in rural areas.

To recapitulate, outdated and inefficient energy infrastructure, fluctuating energy import-export trade, growing energy demand, interregional energy conflict because of scattered energy resources, limited opportunities for improving the economic sector, a low-income scenario in rural areas, and limited utilisation of plentiful renewable energy sources cause a high degree of energy insecurity in rural Central Asia.

Author Contributions: Conceptualization, K.M., W.Z.; methodology, K.M., M.E., C.T., W.Z. and R.G.; resources, K.M.; writing—original draft preparation, K.M.; writing—review and editing, K.M., C.T., M.E., W.Z, R.G.; visualization, K.M.; supervision, W.Z and R.G. All authors have read and agreed to the published version of the manuscript.

Funding: The research work was funded by the Federal Ministry of Education and Research (BMBF) of the Federal Republic of Germany within the CLIENT II funding programme International Partnerships for Sustainable Innovations under the project "ÖkoFlussPlan” (Project ID 01LZ1802A-F).

Institutional Review Board Statement: Not applicable.

Informed Consent Statement: Not applicable.

Data Availability Statement: Not applicable.

Acknowledgments: The authors would like to acknowledge the library of Technische Hochschule Ingolstadt to provide needful resources and support.

Conflicts of Interest: The authors declare no conflict of interest. 


\section{References}

1. Rao, P.S.C.; Miller, J.B.; Wang, Y.D.; Byrne, J.B. Energy-microfinance intervention for below poverty line households in India. Energy Policy 2009, 37, 1694-1712. [CrossRef]

2. Brew-Hammond, A. Energy access in Africa: Challenges ahead. Energy Policy 2010, 38, 2291-2301. [CrossRef]

3. Angelou, N.; Bhatia, M. Capturing the Multi-Dimensionality of Energy Access (English): Live Wire Knowledge Note Series, Washington. 2014. Available online: http:/ / documents.worldbank.org/curated/en/937711468320944879/Capturing-the-multidimensionality-of-energy-access (accessed on 5 April 2020).

4. Carrillo, N. Assessment of Household Energy Access: The Progress out of Energy Poverty Index (PEPI) Toolkit for the Microfinance Sector. Ph.D. Thesis, Technical University of Berlin, Berlin, Germany, 2017.

5. Muhumuza, R.; Zacharopoulos, A.; Mondol, J.D.; Smyth, M.; Pugsley, A. Energy consumption levels and technical approaches for supporting development of alternative energy technologies for rural sectors of developing countries. Renew. Sustain. Energy Rev. 2018, 97, 90-102. [CrossRef]

6. Monyei, C.G.; Akpeji, K.O. Repurposing Electricity Access Research for the Global South: A Tale of Many Disconnects. Joule 2020, 4, 278-281. [CrossRef]

7. Hostettler, S.; Gadgil, A.; Hazboun, E. Sustainable Access to Energy in the Global South; Springer International Publishing: Cham, Switzerland, 2015; ISBN 978-3-319-20208-2.

8. Mainali, B.; Silveira, S. Alternative pathways for providing access to electricity in developing countries. Renew. Energy 2013, 57, 299-310. [CrossRef]

9. Shadrina, E. Renewable Energy in Central Asian Economies: Role in Reducing Regional Energy Insecurity; ADBI Working Paper 993, Tokyo. 2019. Available online: https://www.adb.org/publications/renewable-energy-central-asian-economies (accessed on 5 April 2020).

10. World Bank. Central Asia—Water and Energy Program: Working for Energy and Water Security (English) No. 141508, Washington. 2019. Available online: http://documents.worldbank.org/curated/en/141991567780869624/Central-Asia-Water-and-EnergyProgram-Working-for-Energy-and-Water-Security (accessed on 24 October 2020).

11. World Bank. Surface Area (sq. km). Available online: https:/ / data.worldbank.org/indicator/AG.SRF.TOTL.K2 (accessed on 24 October 2020).

12. World Bank. Population. Available online: https:// data.worldbank.org/indicator/sp.pop.totl (accessed on 20 February 2019).

13. World Bank. GDP (current US\$). Available online: https://data.worldbank.org/indicator/NY.GDP.MKTP.CD (accessed on 30 October 2020).

14. World Bank. GNI per Capita, Atlas Method (Current US\$). Available online: https://data.worldbank.org/indicator/NY.GNP. PCAP.CD (accessed on 30 October 2020).

15. Pohl, B.; Kramer, A.; Hull, W.; Blumstein, S.; Abdullaev, I.; Tais, K.J.R.; Strikeleva, E.; Interwies, E.; Görlitz, S. Rethinking Water in Central Asia: The costs of Inaction and Benefits of Water Cooperation; Swiss Agency of Development and Cooperation (SDC): Berlin, Germany, 2017.

16. Batsaikhan, U.; Dabrowski, M. Central Asia-twenty-five years after the breakup of the USSR. Russ. J. Econ. 2017, 3, 296-320. [CrossRef]

17. Dowling, M.; Wignaraja, G. Central Asia after Fifteen Years of Transition: Growth, Regional Cooperation, and Policy Choices, Philippines. 2006. Available online: https:/ / www.adb.org/sites/default/files/publication/28460/wp03-cars.pdf (accessed on 5 April 2020).

18. Batsaikhan, U.; Dabrowski, M. Central Asia at 25. Available online: https://www.bruegel.org/2017/05/central-asia-at-25/ (accessed on 24 February 2020).

19. Raballand, G.; Kunth, A.; Auty, R. Central Asia's transport cost burden and its impact on trade. Econ. Syst. 2005, $29,6-31$. [CrossRef]

20. Linn, J.F.; Blaxall, M. Central Asia Human Development Report 2005: Bringing Down Barriers: Regional Cooperation for Human Development and Human Security; UNDP Regional Bureau for Europe and the Commonwealth of Independent States: Bratislava, Slovakia, 2005; ISBN 92-95042-34-4.

21. Russell, M. Connectivity in Central Asia: Reconnecting the Silk Road. Available online: https://www.europarl.europa.eu/ RegData/etudes/BRIE/2019/637891/EPRS_BRI(2019)637891_EN.pdf (accessed on 5 April 2020).

22. Bobojonov, I.; Aw-Hassan, A. Impacts of climate change on farm income security in Central Asia: An integrated modeling approach. Agric. Ecosyst. Environ. 2014, 188, 245-255. [CrossRef]

23. Hamidov, A.; Helming, K.; Balla, D. Impact of agricultural land use in Central Asia: A review. Agron. Sustain. Dev. 2016, 36, 77. [CrossRef]

24. USAID. Climate risk profile: Central Asia: Fact Sheet. Available online: https://www.climatelinks.org/sites/default/files/asset/ document/2018-April-30_USAID_CadmusCISF_Climate-Risk-Profile-Central-Asia.pdf (accessed on 30 October 2020).

25. Asian Development Bank. Central Asia Atlas of Natural Resources; Asian Development Bank: Metro Manila, Philippines, 2014; ISBN 978-971-561-886-1.

26. Orlovsky, L.; Orlovsky, N.; Durdyev, A. Dust storms in Turkmenistan. J. Arid Environ. 2005, 60, 83-97. [CrossRef]

27. Indoitu, R.; Orlovsky, L.; Orlovsky, N. Dust storms in Central Asia: Spatial and temporal variations. J. Arid Environ. 2012, 85, 62-70. [CrossRef] 
28. Frenken, K. Irrigation in Central Asia in Figures: AQUASTAT Survey-2012; Food and Agriculture Organization of the United Nations: Rome, Italy, 2013; ISBN 978-92-5-107660-6.

29. Rahaman, M.M. Principles of Transboundary Water Resources Management and Water-related Agreements in Central Asia: An Analysis. Int. J. Water Resour. Dev. 2012, 28, 475-491. [CrossRef]

30. Zou, S.; Jilili, A.; Duan, W.; Maeyer, P.D.; Van de Voorde, T. Human and Natural Impacts on the Water Resources in the Syr Darya River Basin, Central Asia. Sustainability 2019, 11, 3084. [CrossRef]

31. FAO. AQUASTAT Country Profile-Tajikistan, Rome (Italy). 2012. Available online: http://www.fao.org/3/ca0369en/CA0369EN. pdf (accessed on 5 April 2020).

32. Mueller, L.; Saparov, A.; Lischeid, G. (Eds.) Novel Measurement and Assessment Tools for Monitoring and Management of Land and Water Resources in Agricultural Landscapes of Central Asia; Springer: Cham, Switzerland, 2014; ISBN 978-3-319-01016-8.

33. Aminjonov, F. Re-Thinking Central Asian Energy Security: Pitfalls of Export Diversification Policies, Kazakhstan. 2016. Available online: http:/ / library.fes.de/pdf-files/bueros/kasachstan/13546.pdf (accessed on 16 December 2019).

34. IEA. Total Primary Energy Supply (TPES) in Central Asia. Available online: https://www.iea.org/data-and-statistics?country= WORLD\&fuel=Energy $\% 20$ supply\&indicator=Total\%20primary $\% 20$ energy $\% 20$ supply $\% 20($ TPES) $\% 20$ by $\% 20$ source (accessed on 5 April 2020).

35. Christmann, S.; Aw-Hassan, A. Should agricultural research in Central Asia and Caucasus (CAC) re-prioritize its agenda with view to climate change? Agric. Ecosyst. Environ. 2011, 140, 314-316. [CrossRef]

36. Qi, J.; Bobushev, T.S.; Kulmatov, R.; Groisman, P.; Gutman, G. Addressing global change challenges for Central Asian socioecosystems. Front. Earth Sci. 2012, 6, 115-121. [CrossRef]

37. Ariza, C.; Maselli, D.; Kohler, T. Mountains: Our Life, Our Future. Progress and Perspectives on Sustainable Mountain Development from Rio 1992 to Rio 2012 and Beyond; Centre for Development and Environment, University of Bern: Bern, Switzerland, 2013.

38. Xenarios, S.; Gafurov, A.; Schmidt-Vogt, D.; Sehring, J.; Manandhar, S.; Hergarten, C.; Shigaeva, J.; Foggin, M. Climate change and adaptation of mountain societies in Central Asia: Uncertainties, knowledge gaps, and data constraints. Reg. Environ. Change 2019, 19, 1339-1352. [CrossRef]

39. Reyer, C.P.; Otto, I.M.; Adams, S.; Albrecht, T.; Baarsch, F.; Cartsburg, M.; Coumou, D.; Eden, A.; Ludi, E.; Marcus, R.; et al. Climate change impacts in Central Asia and their implications for development. Reg. Environ. Change 2017, 17, 1639-1650. [CrossRef]

40. Kampakis, A. Divesting from fossil fuels in Central Asia: Factors affecting Renewable Energy Transition in Kazakhstan, Kyrgyzstan, Tajikistan. Master Thesis, Vrije Universiteit, Amsterdam, The Netherland, 2015.

41. Abbasi, Z.A.K.; Nawaz, A. Impact of Climate Change Awareness on Climate Change Adaptions and Climate Change Adaptation Issues. PJAR 2020, 36. [CrossRef]

42. Zhang, M.; Chen, Y.; Shen, Y.; Li, B. Tracking climate change in Central Asia through temperature and precipitation extremes. J. Geogr. Sci. 2019, 29, 3-28. [CrossRef]

43. Qi, J.; Kulmatov, R. An Overview of Environmental Issues In Central Asia. In Environmental Problems of Central Asia and their Economic, Social and Security Impacts; Qi, J., Evered, K.T., Eds.; Springer Netherlands: Dordrecht, The Netherlands, 2008; pp. 3-14. ISBN 978-1-4020-8959-6.

44. Junxia, L. Investments in the energy sector of Central Asia: Corruption risk and policy implications. Energy Policy 2019, $133,110912$. [CrossRef]

45. Chen, H.; Liu, H.; Chen, X.; Qiao, Y. Analysis on impacts of hydro-climatic changes and human activities on available water changes in Central Asia. Sci. Total Environ. 2020, 737, 139779. [CrossRef]

46. World Bank. Access to Electricity (\% of Population). Available online: https://data.worldbank.org/indicator/EG.ELC.ACCS.ZS (accessed on 5 March 2021).

47. Toralieva, G. Destruction of Central Asian Electricity Grid: Causes and Implications. Available online: https://www.ceps.eu/ ceps-publications/destruction-central-asian-electricity-grid-causes-and-implications/ (accessed on 5 April 2020).

48. GICA. Central Asian Power System (CAPS). Available online: https:/ /www.gica.global/initiative/central-asian-power-systemcaps (accessed on 23 September 2020).

49. Asia Pacific Energy Portal. Energy and Development in Central Asia: A Statistical Overview of Energy Sectors in Kazakhstan, Kyrgyzstan, Tajikistan, Turkmenistan, and Uzbekistan. Available online: https:/ / www.unescap.org/sites/default/files/Central\% 20Asia\%20Statistical\%20Perspective\%202018_WEB.pdf (accessed on 10 April 2020).

50. World Bank. Central Asia Energy-Water Development Program: Annual Report 2017; No. 132036, Washington D.C., 2018. Available online: http:/ / documents.worldbank.org/curated/en/994621542395781844/Central-Asia-Energy-Water-DevelopmentProgram-Annual-Report-2017 (accessed on 10 April 2020).

51. IEA. Electricity Generation by Source. Available online: https://www.iea.org/ data-and-statistics?country=TAJIKISTAN\&fuel= Energy\%20supply\&indicator=Electricity\%20generation\%20by\%20source (accessed on 10 February 2020).

52. Karatayev, M.; Clarke, M.L. Current Energy Resources in Kazakhstan and the Future Potential of Renewables: A Review. Energy Procedia 2014, 59, 97-104. [CrossRef]

53. Ziesing, H. Scenarios of power demand and supply for Kazakhstan-A view from outside. In Energy Safety: Global and National Aspects; Climate Change Coordination Centre and Nurdana Foundation: Astana, Kazakhstan, 2008. 
54. Ketova, O. Best Practices in Sustainable Energy in Kazakhstan. 2018. Available online: https://www.unece.org/fileadmin/DAM/ project-monitoring/unda/16_17X/A2.1_Implement_Natl_CS/Kazakhstan_EnergySectorReport.pdf (accessed on 10 April 2020).

55. Kadrzhanova, A. Kazakhstan: Power Generation and Distribution Industry. 2013. Available online: http://www.iberglobal.com/ files/kazajstan_power.pdf (accessed on 10 April 2020).

56. NSC. Kyrgyzstan: Brief statistical handbook: Annual publication; Bishkek (Kyrgyzstan). 2018. Available online: http://www.stat. kg/media/publicationarchive/16db2910-6b8d-48f9-80b9-45b7ac3347bd.pdf (accessed on 22 October 2019).

57. PWC. Study for a Power Sector Financing Road Map within Central Asia Regional Economic Cooperation: Kyrgyz Republic, Mobilizing Financing for Priority Projects. 2016. Available online: https://www.carecprogram.org/uploads/CAREC_TA8727_ CountryReport_KyrgyzRepublic.pdf (accessed on 15 January 2019).

58. Gassner, K.B.; Rosenthal, N.; Hankinson, D.J. Analysis of the Kyrgyz Republic's Energy Sector: Final Report. World Bank Energy and Extractives Global Practice ECA Region. 2017. Available online: https:/ / openknowledge.worldbank.org/handle/10986/29 045 (accessed on 20 September 2018).

59. IEC. In-Depth Review of the Energy Efficiency Policy of the Kyrgyz Republic: Energy Charter Protocol on Energy Efficiency and Related Environmental Aspects. Brussels (Belgiumt). 2018. Available online: https:/ / energycharter.org/fileadmin/ DocumentsMedia/IDEER/IDEER-KyrgyzstanEN2018.pdf (accessed on 21 December 2019).

60. World Bank. Electric Power Transmission and Distribution Losses (\% of Output). Available online: https://data.worldbank.org/ indicator/EG.ELC.LOSS.ZS?locations=KG (accessed on 13 February 2019).

61. FAO. National Gender Profile of Agricultural and Rural Livelihoods-Kyrgyz Republic: Country Gender Assessment Series. Ankara (Turkey). 2016. Available online: http:/ /www.fao.org/3/a-i5763e.pdf (accessed on 20 August 2018).

62. World Bank. Heating Assessment for the Urban Building Sector of the Kyrgyz Republic, Bishkek, Kyrgyz Republic. 2015. Available online: https://www.worldbank.org/content/dam/Worldbank/Feature\%20Story/ECA/Central\%20Asia/KG-UrbanHeating-Study-Summary-en.pdf (accessed on 27 March 2021).

63. World Bank. Keeping Warm: Urban Heating Options in the Kyrgyz Republic: Summary Report (English), Washington, DC. 2015. Available online: http:/ / documents.worldbank.org/curated/en/555021468011161504/pdf/97409-WP-P133058-Box391503BPUBLIC-Heating-Assessment-for-Kyrgyz-P133058-Final.pdf (accessed on 27 November 2018).

64. Nabiyeva, K. Renewable Energy and Energy Efficiency in Central Asia: Prospects for German Engagement; Michael Succow Foundation: Greifswald, Germany, 2015.

65. World Bank. Tajikistan's Winter Energy Crisis: Electricity Supply and Demand Alternatives; World Bank: Washington, DC, USA, 2012.

66. Swinkels, R. Assessment of Household Energy Deprivation in Tajikistan: Policy Options for Socially Responsible Reform in the Energy Sector; Washington DC. 2014. Available online: http://documents.worldbank.org/curated/en/137401468303580524 / Assessment-of-household-energy-deprivation-in-Tajikistan-policy-options-for-socially-responsible-reform-in-the-energysector (accessed on 28 February 2021).

67. IEA. Electricity Imports vs. Exports. Available online: https://www.iea.org/data-and-statistics?country=KYRGYZSTAN\&fuel= Imports\%2Fexports\&indicator=ElecImportsExports (accessed on 21 October 2020).

68. World Bank. The Costs of Irrigation Inefficiency in Tajikistan; World Bank: Washington, DC, USA, 2017.

69. Fields, D.; Kochnakyan, A.; Stuggins, G.; Besant-Jones, J. Tajikistan's Winter Energy Crisis; The World Bank: Washington, DC, USA, 2013; ISBN 978-0-8213-9967-5.

70. Gerlitz, L.; Steirou, E.; Schneider, C.; Moron, V.; Vorogushyn, S.; Merz, B. Variability of the Cold Season Climate in Central Asia. Part I: Weather Types and Their Tropical and Extratropical Drivers. J. Climate 2018, 31, 7185-7207. [CrossRef]

71. Kerimray, A.; de Miglio, R.; Rojas-Solórzano, L.; Gallachóir, B.Ó. Household Energy Consumption and Energy Poverty in Kazakhstan; International Association for Energy Economics: 2017. Available online: https://www.iaee.org/en/publications/ newsletterdl.aspx?id=382 (accessed on 4 October 2020).

72. Meteotest AG. Meteonorm; Meteotest AG: Bern, Switzerland, 2018.

73. IEA. Total Final Energy Consumption by Sectors in Central Asia. Available online: https://www.iea.org/data-and-statistics? country=TAJIKISTAN\&fuel=Energy $\% 20$ consumption\&indicator=Total $\% 20$ final $\% 20$ consumption $\% 20$ (TFC) $\% 20$ by $\% 20$ sector (accessed on 5 April 2020).

74. Fodde, E. Traditional Earthen Building Techniques in Central Asia. Int. J. Archit. Herit. 2009, 3, 145-168. [CrossRef]

75. Howie, P.; Atakhanova, Z. Household Coal Demand in Rural Kazakhstan: Subsidies, Efficiency, and Alternatives. Energy Policy Res. 2017, 4, 55-64. [CrossRef]

76. World Bank. Fueling Kyrgyzstan's Transition to Clean Household Heating Solutions; World Bank: Washington, DC, USA, 2020.

77. Kerimray, A.; de Miglio, R.; Rojas-Solórzano, L.; Gallachóir, B.Ó. Incidence of District Heating and Natural Gas Networks on Energy Poverty across Kazakhstan. In Proceedings of the 1st IAEE Eurasian Conference; Energy Economics Emerging from the Caspian Region: Challenges and Opportunities; Baku, Azerbaijan, 28-31 August 2016, 2016.

78. Kenessariyev, U.; Golub, A.; Brody, M.; Dosmukhametov, A.; Amrin, M.; Erzhanova, A.; Kenessary, D. Human Health Cost of Air Pollution in Kazakhstan. JEP 2013, 4, 869-876. [CrossRef]

79. Hall, K. Mountain Societies Research Institute About MSRI Resources Partnerships MSRI Publications CAARF Briefs Staff Publications Knowledge Hub Institute of Public Policy and Administration about IPPA IPPA Publications Policy Briefs External Staff Publications Civil Society Initiative Publications Cultural Heritage and Humanities Unit Cultural Heritage Book Series 
Research Papers Supporting Energy Efficiency and Renewables Uptake in Rural Communities in Mountainous Kyrgyzstan. Available online: https:/ /www.ucentralasia.org/Research/Item/1711/EN (accessed on 5 January 2021).

80. World Bank and Factfish. Kyrgyzstan: Forest Area (sq. km). Available online: http://www.factfish.com/statistic-country/ kyrgyzstan/forest\%20area (accessed on 17 September 2018).

81. World Bank and Factfish. Kyrgyzstan: CO2 emissions from solid fuel consumption (kt). Available online: http://www.factfish com/statistic-country/kyrgyzstan/co2\%20emissions\%20from\%20solid\%20fuel\%20consumption (accessed on 17 September 2018).

82. Lauermann, M.; Betz, F.; Mehta, K.; Thevs, N.; Ehrenwirth, M.; Zörner, W.; Cyffka, B. Preservation of Selected Ecosystem Services in the Floodplains of the Naryn River (Kyrgyzstan): Introducing the ÖkoFlussPlan Project. In Geographica Augustana; Institut für Geographie, Universität Augsburg: Heidelberg, Germany, 2020; pp. 47-53. ISBN 1862-8680.

83. Balabanyan, A.; Hofer, K.; Finn, J.; Hankinson, D. Keeping Warm: Urban Heating Options in Tajikistan: Summary Report. 2015. Available online: http:/ / documents.worldbank.org/curated/en/353391467986295623/Keeping-warm-urban-heating-optionsin-Tajikistan-summary-report (accessed on 25 January 2021).

84. Laldjebaev, M. Energy Security, Poverty and Sovereignty in Mountain Communities of Tajikistan. Ph.D. Thesis, Cornell University, New York, NY, USA, 2017.

85. World Bank. GDP Per Capita (Current US\$). Available online: https://data.worldbank.org/indicator/NY.GDP.PCAP.CD?end= $2017 \&$ start $=1960$ (accessed on 17 October 2020).

86. OWID. Death Rates from Indoor Air Pollution. Available online: https://ourworldindata.org/grapher/death-rate-by-sourcefrom-indoor-air-pollution?time=2017 (accessed on 17 October 2020).

87. Jacobsen, R. Energy Efficient Building Methods for Tajikistan; Norges Naturvernforbund: Grensen, Norway, 2009.

88. Mislimshoeva, B.; Hable, R.; Fezakov, M.; Samimi, C.; Abdulnazarov, A.; Koellner, T. Factors Influencing Households' Firewood Consumption in the Western Pamirs, Tajikistan. Mt. Res. Dev. 2014, 34, 147-156. [CrossRef]

89. Bekturganov, Z.; Tussupova, K.; Berndtsson, R.; Sharapatova, N.; Aryngazin, K.; Zhanasova, M. Water Related Health Problems in Central Asia-A Review. Water 2016, 8, 219. [CrossRef]

90. Russell, M. Water in Central Asia: An Increasingly Scarce Resource. Available online: https://www.europarl.europa.eu/RegData/ etudes/BRIE/2018/625181/EPRS_BRI(2018)625181_EN.pdf (accessed on 4 October 2020).

91. Kerimray, A.; de Miglio, R.; Rojas-Solórzano, L.; Ó Gallachóir, B.P. Causes of energy poverty in a cold and resource-rich country: Evidence from Kazakhstan. Local Environ. 2018, 23, 178-197. [CrossRef]

92. FAO. National gender profile of agricultural and rural livelihoods-Tajikistan: Country gender assessment series. Available online: http:/ / www.fao.org/3/a-i5766e.pdf (accessed on 4 October 2020).

93. Shadrina, E. Non-Hydropower Renewable Energy in Central Asia: Assessment of Deployment Status and Analysis of Underlying Factors. Energies 2020, 13, 2963. [CrossRef]

94. Abylkasymova, A.; Eshchanov, B.; Overland, I.; Moldokanov, D.; Aminjonov, F.; Vakulchuk, R. Hydropower Potential of the Central Asian Countries; Central Asia Data-Gathering and Analysis Team. 2019. Available online: https://www.researchgate. net/publication/331716216_Hydropower_Potential_of_the_Central_Asian_Countries (accessed on 4 October 2020).

95. Petrov, G. Resources and Use of Renewable Energy in Tajikistan; 2010. Available online: https://www.researchgate.net/ publication/336796453_Resources_and_use_of_renewable_energy_in_Tajikistan_2010g?chanel=doi\&linkId=5db264f6458515 5e27ff1208\&showFulltext=true (accessed on 4 March 2021).

96. Nurdavletova, S.; Akatayeva, A. The renewable energy in the regional development of Central Asia. SSI 2018, 162-185. [CrossRef]

97. Eshchanov, B.R.; Grinwis Plaat Stultjes, M.; Eshchanov, R.A.; Salaev, S.K. Prospects of renewable energy penetration in Uzbekistan-Perception of the Khorezmian people. Renewable and Sustainable Energy Reviews 2013, 21, 789-797. [CrossRef]

98. Karimov, K.S.; Akhmedov, K.M.; Abid, M.; Petrov, G.N. Effective management of combined renewable energy resources in Tajikistan. Sci. Total Environ. 2013, 461-462, 835-838. [CrossRef] [PubMed]

99. Baybagyshov, E.; Degembaeva, N. Analysis of usage of the renewable energy in Kyrgyzstan. IOP Conf. Ser. Earth Environ. Sci. 2019, 249, 12021. [CrossRef]

100. IEA. Uzbekistan Energy Profile. Available online: https:/ / www.iea.org/reports/uzbekistan-energy-profile (accessed on 29 April 2021$).$

101. Yoshino, N.; Taghizadeh-Hesary, F.; Youngho, C.; Le, T.-H. (Eds.) Energy Insecurity in Asia: Challenges, Solutions and Renewable Energy; Asian Development Bank Institute: Tokyo, Japan, 2020; ISBN 978-4-89974-111-4.

102. IRENA. Trends in Renewable Energy: Installed Capacity. Available online: https://public.tableau.com/views/IRENARETimeSeries/ Charts?:embed=y\&:showVizHome=no\&publish=yes\&:toolbar=no (accessed on 29 April 2021).

103. Abylkasymova, A.; Moldokanov, D.; Eshchanov, B.; Overland, I.; Aminjonov, F.; Vakulchuk, R. Wind Power Potential of the Central Asian Countries. Available online: http://www.osce-academy.net/upload/file/Wind_Potential_CADGAT_Report17.pdf (accessed on 29 April 2021).

104. Gubaidullina, M.; Balaubaeva, B.; Karimova, S. Renewable energy and the regional prospect on sustainable development of Central Asia. IRILY 2017, 80, 4-17. [CrossRef]

105. Kiseleva, S.V.; Popel', O.S.; Tarasenko, A.B.; Avezov, R.R. Efficiency estimation for the grid-tie photovoltaic stations construction in some regions of Central Asia and Transcaucasia. Appl. Sol. Energy 2017, 53, 306-311. [CrossRef]

106. Zavadskiy, V.; Revalde, G. Problems of development of renewable energy facilities in rural regions on example of Kazakhstan In 19th International Scientific Conference Engineering for Rural Development Proceedings; Latvia University of Life Sciences and Technologies, Faculty of Engineering: Jelgava, Latvia, 2020. 
107. Vakhguelt, A. Renewable Energy Potential of Kazakhstan. DDF 2017, 379, 189-194. [CrossRef]

108. Karatayev, M.; Hall, S.; Kalyuzhnova, Y.; Clarke, M.L. Renewable energy technology uptake in Kazakhstan: Policy drivers and barriers in a transitional economy. Renew. Sustain. Energy Rev. 2016, 66, 120-136. [CrossRef]

109. Abidov, A.; Ryspaev, T.; Satybaldyev, A.; Gorbacheva, A. Comparative Analysis of Some Types of Renewable Energy Sources. Industrija 2020, 46, 93-111

110. Schulz, D.; Ahrorova, A.D.; Halimjanova, M.K.; Kholov, K.H. The energy supply for mountain settlements in Tajikistan based on renewable energy sources. In Energy Production and Management in the 21st Century; ENERGY QUEST 2014, Ekateringburg, Russia, 23-25 Apr. 2014; Brebbia, C.A., Magaril, E.R., Khodorovsky, M.Y., Eds.; WIT Press: Southampton, UK, 2014; pp. 971-978.

111. Doukas, H.; Marinakis, V.; Karakosta, C.; Psarras, J. Promoting renewables in the energy sector of Tajikistan. Renew. Energy 2012, 39, 411-418. [CrossRef]

112. Mehta, K.; Ehrenwirth, M.; Trinkl, C.; Zörner, W.; Greenough, R. A Parametric Study on the Feasibility of Solar-thermal Space Heating and Hot Water Preparation under Cold Climates in Central Asian Rural Areas. In Proceedings of the 13th International Conference on Solar Energy for Buildings and Industry, EuroSun 2020, Virtual, 1-3 September 2020. 